\title{
Tumor cell invasion of collagen matrices requires coordinate lipid agonist-induced G-protein and membrane-type matrix metalloproteinase-I-dependent signaling
}

\author{
Kevin E Fisher ${ }^{1,2}$, Andreia Pop ${ }^{1}$, Wonshill Koh ${ }^{1,2}$, Nicholas J Anthis ${ }^{1}$, W \\ Brian Saunders ${ }^{1}$ and George E Davis*1,2,3
}

Address: ${ }^{1}$ Department of Pathology and Laboratory Medicine, Texas A\&M University System Health Science Center, College Station, TX 77843, USA, ${ }^{2}$ Department of Medical Pharmacology and Physiology, University of Missouri School of Medicine, Columbia, MO 65212, USA and ${ }^{3}$ Department of Pathology and Anatomical Sciences, University of Missouri School of Medicine, Columbia, MO 65212, USA

Email: Kevin E Fisher - kefgfd@mizzou.edu; Andreia Pop - arpopmd@yahoo.com; Wonshill Koh - wkfxc@mizzou.edu; Nicholas J Anthis - nick.anthis@bioch.ox.ac.uk; W Brian Saunders - bsaunders@cvm.tamu.edu;

George E Davis* - davisgeo@health.missouri.edu

* Corresponding author

Published: 08 December 2006

Molecular Cancer 2006, 5:69 doi:10.1 186/1476-4598-5-69
Received: 04 August 2006

Accepted: 08 December 2006

This article is available from: http://www.molecular-cancer.com/content/5/I/69

(C) 2006 Fisher et al; licensee BioMed Central Ltd.

This is an Open Access article distributed under the terms of the Creative Commons Attribution License (http://creativecommons.org/licenses/by/2.0), which permits unrestricted use, distribution, and reproduction in any medium, provided the original work is properly cited.

\begin{abstract}
Background: Lysophosphatidic acid (LPA) and sphingosine I-phosphate (SIP) are bioactive lipid signaling molecules implicated in tumor dissemination. Membrane-type matrix metalloproteinase I (MTI-MMP) is a membrane-tethered collagenase thought to be involved in tumor invasion via extracellular matrix degradation. In this study, we investigated the molecular requirements for LPA- and SIP-regulated tumor cell migration in two dimensions (2D) and invasion of three-dimensional (3D) collagen matrices and, in particular, evaluated the role of MTI-MMP in this process.

Results: LPA stimulated while SIP inhibited migration of most tumor lines in Boyden chamber assays. Conversely, HTI 080 fibrosarcoma cells migrated in response to both lipids. HTI 080 cells also markedly invaded 3D collagen matrices ( $700 \mu \mathrm{m}$ over 48 hours) in response to either lipid. siRNA targeting of $\mathrm{LPA}_{\mid}$and Racl, or SIP, Racl, and Cdc42 specifically inhibited LPA- or SIP-induced HTI080 invasion, respectively. Analysis of LPA-induced HTI080 motility on $2 \mathrm{D}$ substrates vs. 3D matrices revealed that synthetic MMP inhibitors markedly reduced the distance $(\sim 125 \mu \mathrm{m}$ vs. $\sim 45$ $\mu \mathrm{m})$ and velocity of invasion $(\sim 0.09 \mu \mathrm{m} / \mathrm{min}$ vs. $\sim 0.03 \mu \mathrm{m} / \mathrm{min})$ only when cells navigated 3D matrices signifying a role for MMPs exclusively in invasion. Additionally, tissue inhibitors of metalloproteinases (TIMPs)-2, -3 , and -4 , but not TIMP-I, blocked lipid agonist-induced invasion indicating a role for membrane-type (MT)-MMPs. Furthermore, MTI-MMP expression in several tumor lines directly correlated with LPA-induced invasion. HEK293s, which neither express MTIMMP nor invade in the presence of LPA, were transfected with MTI-MMP CDNA, and subsequently invaded in response to LPA. When HTI080 cells were seeded on top of or within collagen matrices, siRNA targeting of MTI-MMP, but not other MMPs, inhibited lipid agonist-induced invasion establishing a requisite role for MTI-MMP in this process.

Conclusion: LPA is a fundamental regulator of MTI-MMP-dependent tumor cell invasion of 3D collagen matrices. In contrast, SIP appears to act as an inhibitory stimulus in most cases, while stimulating only select tumor lines. MTI-MMP is required only when tumor cells navigate $3 D$ barriers and not when cells migrate on $2 \mathrm{D}$ substrata. We demonstrate that tumor cells require coordinate regulation of LPA/SIP receptors and Rho GTPases to migrate, and additionally, require MTI-MMP in order to invade collagen matrices during neoplastic progression.
\end{abstract}




\section{Background}

Tumor cell invasion is a complex process involving genetic and cellular alterations which lead to proteolysis and dispersion through three-dimensional biological barriers [1-4]. Type I collagen is the most abundant component of the extracellular matrix (ECM), and is therefore a significant obstacle for tumor cell dissemination into the lymphatics, vasculature, and surrounding areas $[5,6]$. Thus, in most cases, collagen must be degraded in order for tumor cells to spread into surrounding anatomic structures and metastasize [7]. Cell migration, governed by polarity and reorganization of the cellular cytoskeleton, is also an integral aspect of tumor cell invasion $[8,9]$. Dissecting the molecular requirements of tumor cell migration and invasion is necessary because the latter, in conjunction with metastasis, is a significant cause of morbidity and mortality in cancer patients [10].

Recent reports have identified two lipid signaling molecules, lysophosphatidic acid (LPA) and sphingosine 1phosphate (S1P), in many critical biological events such as development, angiogenesis, inflammation, and wound repair [11-15]. LPA and S1P function as extracellular lipid agonists which activate a subfamily of $\mathrm{G}$ protein-coupled receptors (GPCRs) and subsequent downstream effectors such as the small GTPases RhoA, Rac1, and Cdc42 [1620]. In addition to fundamental cellular signaling, LPA, particularly in ovarian cancer, and S1P have been implicated in tumor cell proliferation, anti-apoptosis, cytoskeletal rearrangement and migration, and invasion [21-26]. $\mathrm{LPA}_{1-3}$ receptors are thought to be involved in cell motility and are aberrantly expressed in cancer cells $[25,27]$. S1 $\mathrm{P}_{1-}$ ${ }_{3}$ are also involved in the regulation of cell migration and play important roles in the vascular system $[11,15]$.

Additional reports have linked LPA and S1P to the matrix metalloproteinases (MMPs) $[24,28,29]$. The role of MMPs in tumor invasion has been well documented [30-33] and clinical cancer therapeutic trials have sought to target these molecules albeit with disappointing results [34,35]. Membrane-type matrix metalloproteinase 1 (MT1-MMP), also known as MMP-14, is a membrane-bound collagenase that has been shown to localize to the leading edge of invading cells, degrade surrounding extracellular matrix, and play a pivotal role in cancer cell dissemination [36-39]. The objective of the current study, therefore, is to further characterize the roles of LPA, S1P, and MMPs (specifically MT1-MMP) in the processes of tumor cell migration and invasion using both 2D migration analysis and 3D type I collagen invasion assays.

Our data demonstrate that LPA stimulated and S1P inhibited migration of most tumor lines tested. In contrast, HT1080 fibrosarcoma cells migrated in response to both lipids. Invasion of 3D collagen matrices of HT1080 cells, but not migration in either Boyden chambers or on collagen-coated plastic, was blocked in the presence of synthetic MMP inhibitors, and TIMP-2, -3 , or -4 . This indicates that lipid-induced invasion of $3 \mathrm{D}$ collagen matrices is an MT-MMP-dependent event. Transfection of HT1080 cells with siRNAs identified $\mathrm{LPA}_{1}, \mathrm{~S}_{1} \mathrm{P}_{1}$, Rac1, Cdc42, and MT1-MMP as key components of the invasion response. Additional experiments revealed that SKOV3 and HEK293 cell lines, which express low levels of MT1MMP, do not invade LPA-containing 3D collagen matrices despite a marked ability to undergo LPA-induced migration. When HEK293 were transfected with cDNA encoding MT1-MMP, LPA-induced invasion of 3D collagen matrices occurred. Our results demonstrate that lipid agonist-induced tumor cell invasion requires MT1-MMP, and its signaling occurs via $\mathrm{LPA}_{1}, \mathrm{~S}_{1} \mathrm{P}_{1}, \mathrm{Rac} 1$, and Cdc42. We propose that coordinated signaling events between LPA and S1P receptors, their effectors, and MT1-MMP are required during tumor cell invasion of 3D collagen matrices, but MT1-MMP is not required for tumor motility on 2D collagen substrates.

\section{Results \\ LPA stimulates while SIP either inhibits or stimulates migration of tumor cells}

To study the effects of LPA and S1P on migration of tumor cell lines, modified Boyden chambers were utilized. Cells were allowed to migrate for 4 hours in the presence or absence of LPA or S1P. LPA stimulated migration in all tumor cell lines examined, while S1P blocked migration in almost all lines (Fig. 1). These data identified LPA as the most potent migratory stimulus for the tumor cell lines evaluated compared to chemotactic growth factors such as EGF, FGF-2, HB-EGF, IGF-1, and PDGF (data not shown). Thus, in this study we focused on LPA as a stimulus for tumor cell migration and invasion.

Four cell lines were selected for further study due to their marked LPA-migration response namely A2058 melanoma, SKOV3 ovarian carcinoma, human embryonic kidney (HEK) 293, and HT1080 fibrosarcoma. We have previously shown that S1P strongly influences invasive behavior of human endothelial cells (another highly invasive cell type) in $3 \mathrm{D}$ collagen matrices $[28,40]$. The effects of S1P were therefore also evaluated in these cell lines. LPA produced a strong migratory response for these cell lines, and in all but one case (HT1080) S1P inhibited migration. Interestingly, HT1080 cells exhibited a strong migratory response in the presence of both LPA and S1P, contrary to the trend of the other cell lines. This result is particularly intriguing because HT1080 cells are among the most invasive tumor cell lines in both in vivo and in vitro settings $[41,42]$, suggesting a role for S1P responsiveness in highly invasive tumor cells. 


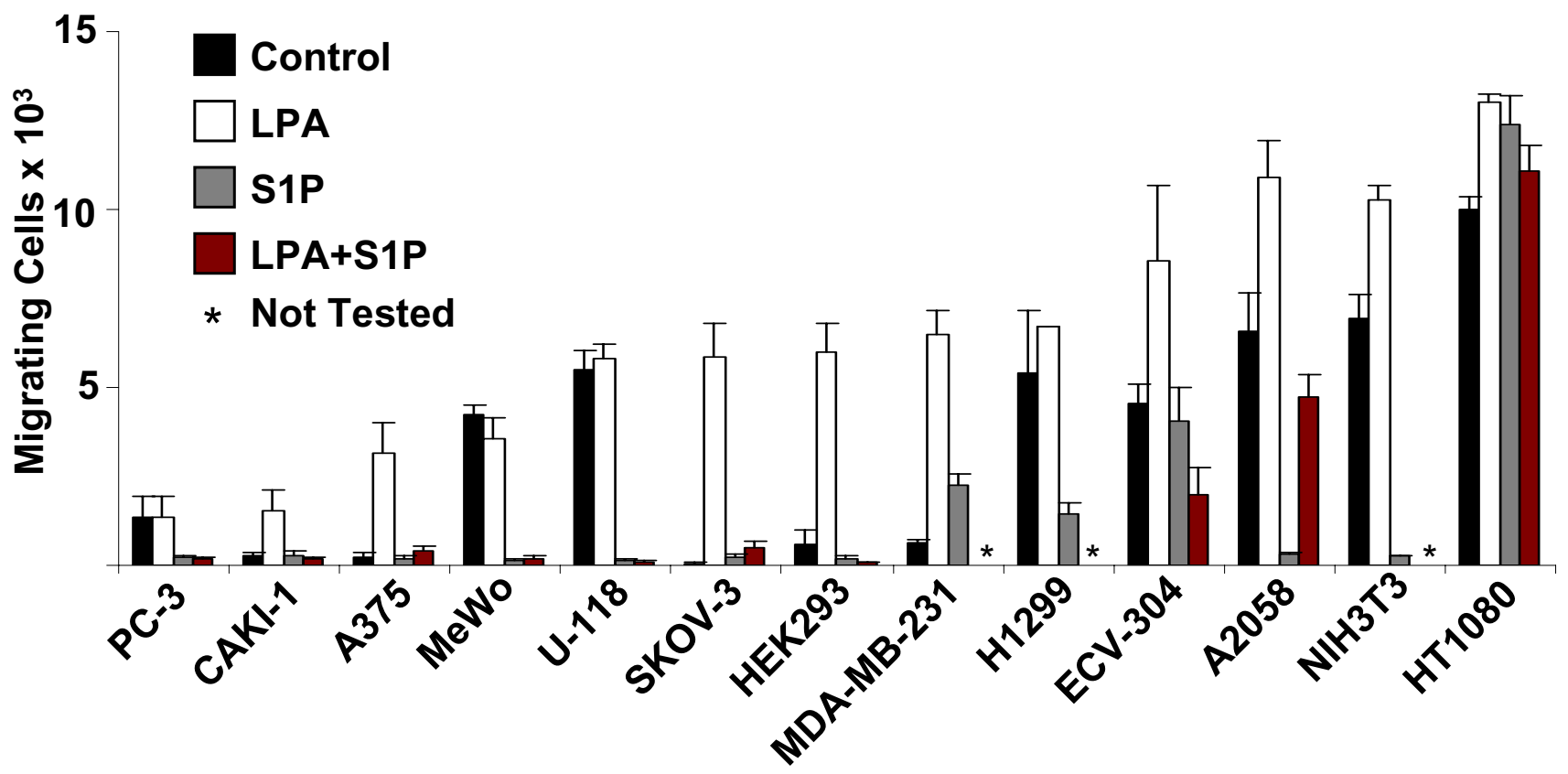

Figure I

LPA stimulates and SIP inhibits migration of most tumor cell lines. Tumor cell migration analysis was performed on $8 \mu \mathrm{m}$ polycarbonate gelatin-coated membranes and $20 \mu \mathrm{g} / \mathrm{ml}$ of fibronectin. LPA and/or SIP (I $\mu \mathrm{M}$ ) were added to the lower chambers and cells were allowed to migrate for 4 hours. Membranes were removed, stained, and migrating cells were quantitated using Scion ${ }^{\circledR}$ software and Microsoft Excel ${ }^{\circledR}$. Data are expressed as mean number of migrating cells $\times 10^{3}( \pm$ S.D.) and represent the results of quadruplicate experiments.

Tumor cell invasion of 3D collagen matrices mimics the lipid agonist migration profile in select cell lines

An in vitro A/2 96-well invasion assay was utilized to study the effects of LPA and S1P on tumor cell invasion of highly concentrated $(3.75 \mathrm{mg} / \mathrm{ml}$ or $2.0 \mathrm{mg} / \mathrm{ml}) 3 \mathrm{D}$ type I collagen gels. LPA or S1P were polymerized in collagen gels at $1 \mu \mathrm{M}$, and the four selected cell lines were placed on the surface of either 3.75 or $2.0 \mathrm{mg} / \mathrm{ml}$ collagen matrices and allowed to invade for 48 hours. Cultures were then fixed and stained for imaging and quantification as shown in Fig. 2A and 2B. Invading cultures are presented as cross-sections to allow visualization of the monolayer (arrows) and the underlying collagen matrix containing invading tumor cells. The HT1080 cell line invaded and migrated dramatically in response to both LPA and S1P (Fig. 1 and Fig. 2). Invasion of the A2058 cell line was stimulated by LPA, but was inhibited by S1P, consistent with the migration profile of this cell line (Fig. 1 and 2A). SKOV3 and HEK293 cells markedly migrated in response to LPA in migration assays (Fig. 1), but were unable to invade $3 \mathrm{D}$ collagen matrices in response to these lipids (Fig. 2B).
Time-Iapse analysis of LPA and SIP-induced tumor invasion of collagen matrices

Additional experiments utilized a new method for timelapse analysis of tumor cell invasion. In this assay, collagen gels were placed into thin walled square glass casings. Tumor cells were then seeded onto the surface of the gel and the casings were placed horizontally so that tumor invasion could be imaged parallel to the surface of the gel and monolayer. Invasion time course experiments revealed that LPA or S1P significantly increased the rate of invasion of HT1080 cells as compared to DMEM control (Fig. 3A, B, and 3D and Table 1). When $3.75 \mathrm{mg} / \mathrm{ml}$ type I collagen gels containing either LPA or S1P were used, HT1080 cells invade $\sim 700 \mu \mathrm{m}$ in 48 hours at a rate of $14-$ $15 \mu \mathrm{m} / \mathrm{hr}$ (See additional file 1: LPA Invasion to view 24 hours of the time-lapse imaging). Notably, the addition of a synthetic inhibitor of MMPs (GM6001) completely blocked LPA-induced invasion of $3 \mathrm{D}$ collagen matrices over this time period (Fig. 3C, D and Table 1; see additional file 2: LPA+GM6001 Invasion to view 24 hours of the time-lapse imaging) establishing a requirement for MMPs in this process (see later on). 

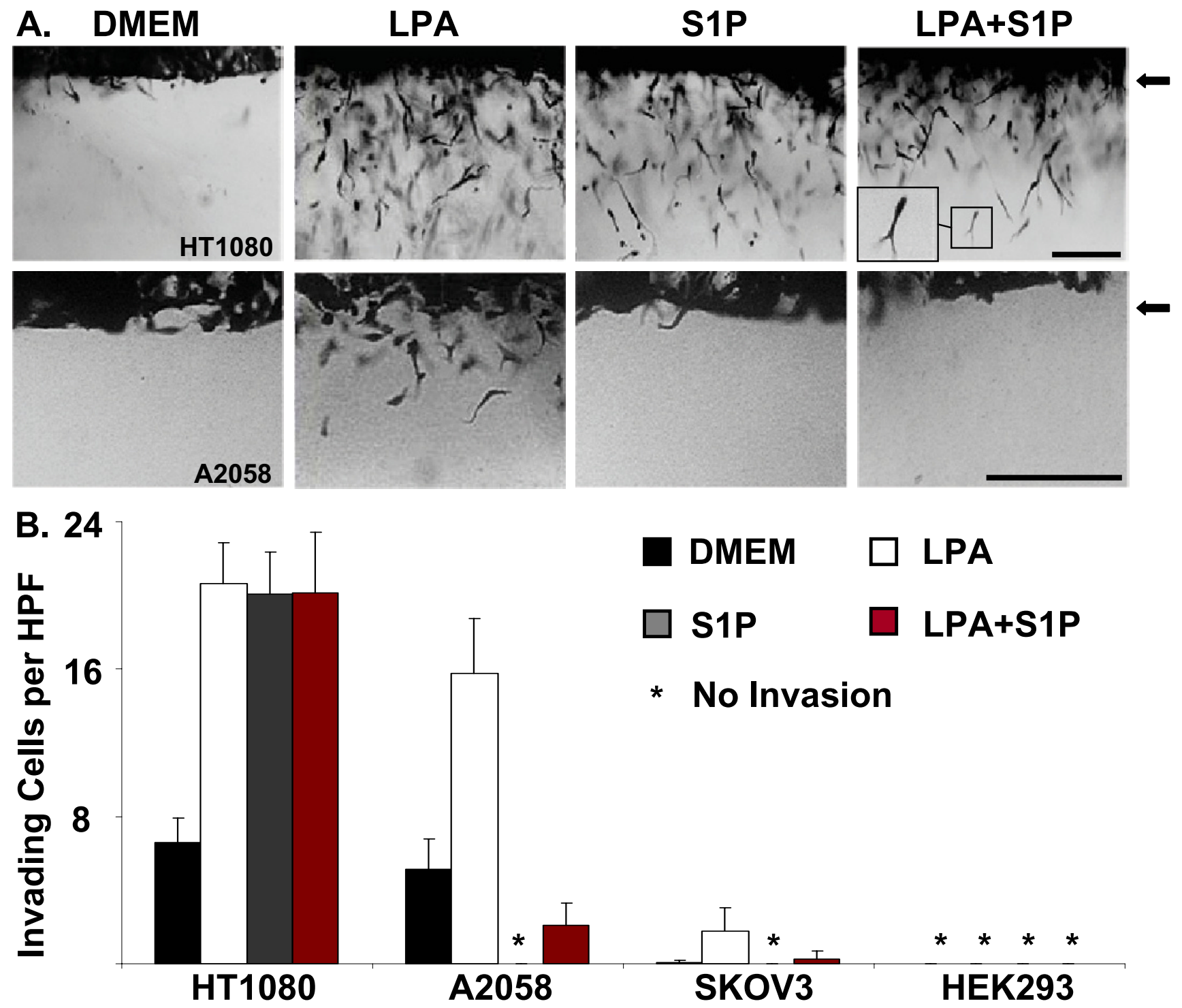

* No Invasion

Figure 2

LPA and SIP regulate tumor cell invasion of 3D collagen matrices. (A) HTI080, A2058, SKOV3 or HEK293 cells were induced to invade 3D collagen gels $(3.75 \mathrm{mg} / \mathrm{ml}$ or $2.0 \mathrm{mg} / \mathrm{ml})$ under serum-free conditions in the presence or absence of LPA alone (I $\mu \mathrm{M})$, SIP alone (I $\mu \mathrm{M})$, or both LPA and SIP (I $\mu$ M each). After 48 hours, cultures were fixed, stained, and images were acquired to demonstrate the effects of LPA and SIP on tumor cell invasion. Arrowheads indicate the position of the tumor cell monolayer at the initiation of invasion. Magnification $=20 \times$. Scale bar $=50 \mu \mathrm{m}$. Inset $($ panel $A)=$ higher power magnification of invading HTI080 cell. (B) Quantitation of tumor invasion from panel A. Data are expressed as mean numbers of invading cells per HPF $(20 \times)$ ( \pm S.D.) from a minimum of 20 fields.

\section{SIP and LPA stimulate HTI080 invasion of 3D type I} collagen matrices through SIP, LPA, Racl, and Cdc42

LPA and S1P have been shown to bind and signal through GPCRs [12,18,27]. Therefore, we elected to characterize which receptors were involved in lipid-induced invasion. Treatment of HT1080 cells with $100 \mathrm{ng} / \mu \mathrm{l}$ of pertussis toxin (PTX) blocked invasion (Fig. 4A) suggesting a role for GPCRs in this process, particularly those that signal through $\mathrm{G}_{\alpha \mathrm{i}}[43,44]$. To identify the receptors required for invasion, siRNAs targeting $\mathrm{LPA}_{1-3}$ and $\mathrm{S}_{1} \mathrm{P}_{1-3}$ receptors were used. Interestingly, when HT1080 cells were allowed to invade in the presence of LPA, invasion was blocked only by siRNAs targeting $\mathrm{LPA}_{1}$ (Fig. $4 \mathrm{~B}$ and data not shown). When HT1080 cells were allowed to invade in the presence of S1P, invasion was blocked by siRNAs targeting only $\mathrm{S}_{1} \mathrm{P}_{1}$ (Fig. 4B and data not shown). Efficiency 


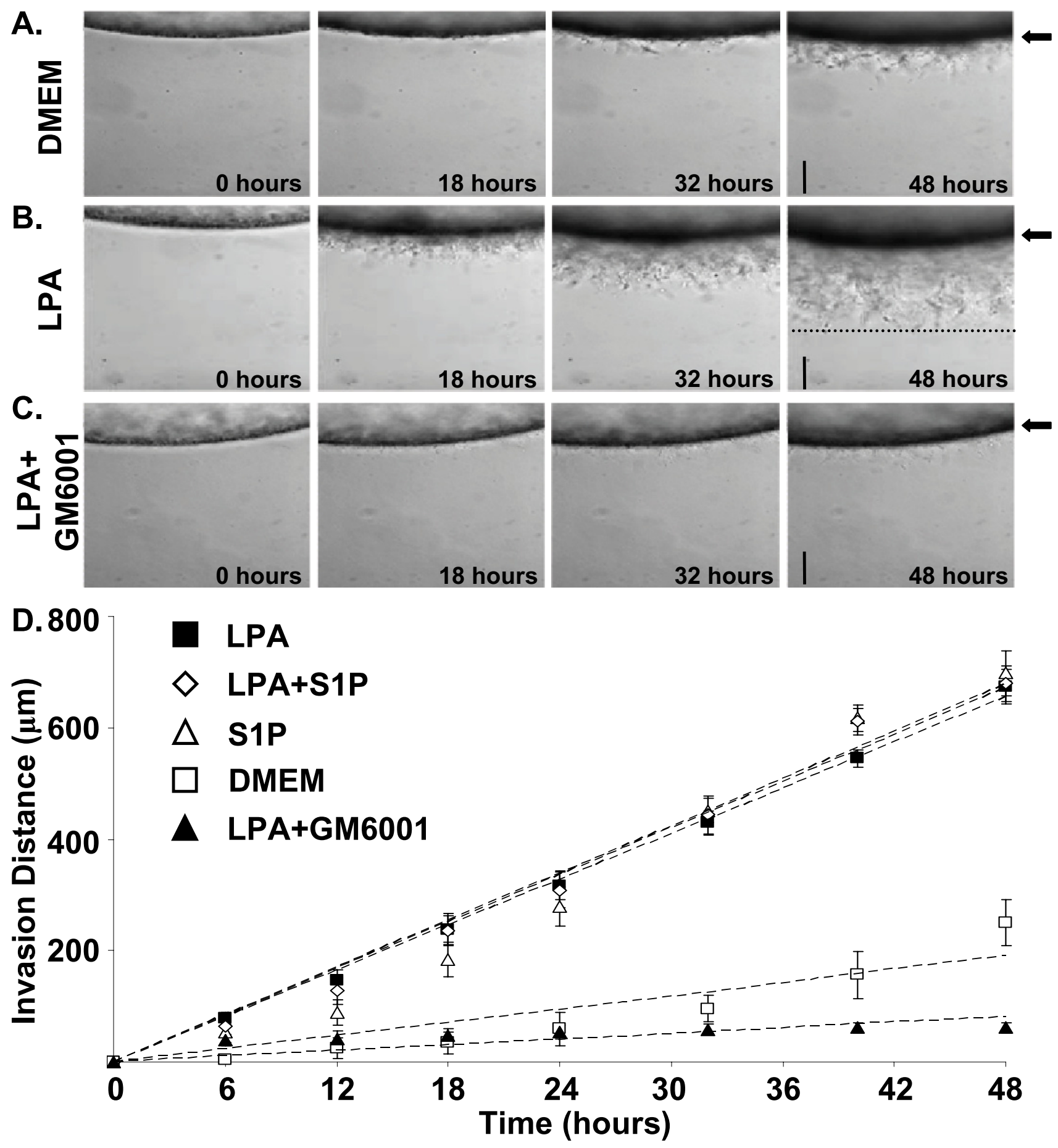

Figure 3

Time-lapse analysis of HT I 080 invasion: LPA and SIP induce $\sim 700 \mu \mathrm{m}$ of invasion of 3D collagen matrices. (A) HTI080 cells were seeded onto $3.75 \mathrm{mg} / \mathrm{ml}$ collagen gels in glass casings (see methods for details) and allowed to invade for 48 hours in the presence of DMEM, LPA, SIP, LPA and SIP (I $\mu$ M each) or LPA (I $\mu M)+$ GM600I (5 $\mu$ M). Digital images of representative fields were captured at ten minute intervals. Using Metamorph ${ }^{\circledR}$, invasion distance measurements at each time point from triplicate wells were obtained $(n=15)$. Magnification $=10 \times$. Scale bars $=200 \mu \mathrm{m}$. (B) Data from panel A were plotted versus time and rates of invasion were calculated using linear regression (see Table I). Data are expressed as mean invasion distance ( $n=3$ wells, \pm S.D.) for each time point from triplicate experiments. 
Table I: LPA and SIP accelerate MTI-MMP-mediated HTI 080 invasion in 3D collagen matrices

\begin{tabular}{ccc}
\hline Condition & Rate of Invasion $(\mu \mathrm{m} / \mathbf{h r})$ & $\mathbf{R}^{\mathbf{2}}$ \\
\hline DMEM & 4.930 & 0.8977 \\
LPA & 13.971 & 0.9986 \\
SIP & 15.672 & 0.9777 \\
LPA + SIP & 14.941 & 0.9916 \\
LPA + GM600I & 1.010 & 0.6971 \\
Luciferase* & 13.873 & 0.9997 \\
Scrambled MTI-MMP* & 13.532 & 0.9988 \\
si MTI-MMP* & 5.366 & 0.9584
\end{tabular}

HTI080 cells were allowed to invade for 48 hours in the presence or absence of the specified lipid. siRNA treated HTI080 cells (Luciferase, MTIMMP, or a control scrambled MTI-MMP) invaded in the presence of I $\mu$ M LPA. Invasion distances were obtained with Metamorph ${ }^{\circledR}$ software by measuring pixel distance at each time point (five measurements per time point of duplicate or triplicate experiments.) Rates of invasion were calculated using linear regression analysis. $\mathrm{R}^{2}$ values denote the predictive potential of distance given time where I.0 equals an exact correlation $(*$ denotes separate experiment).

and specificity of mRNA knockdown was confirmed by Real-Time Quantitative PCR analysis (Fig. 4C). These data suggest that LPA- and S1P-induced invasion signal through different receptors and are thus dissociable processes. These data are consistent with the observed inhibition of invasion by PTX.

We then investigated which of the GPCR effectors were involved in lipid-induced invasion in our system. RhoA, Rac1, and Cdc42 have each been implicated in tumor motility and invasion $[45,46]$, are downstream effectors of both $\mathrm{LPA}_{1}$ and $\mathrm{S1P}_{1}[47,48]$, and therefore were candidates for targeting. We transfected HT1080 cells with siRNAs targeting either RhoA, Rac1, Cdc42, or control siRNAs (Luciferase and Lamin A/C) and assessed invasion in the presence of $1 \mu \mathrm{M} \mathrm{LPA}$ or S1P. siRNA targeting of RhoA had no effect on invasion in the presence of either lipid (Fig. 5A). siRNA targeting of Rac1 inhibited invasion in the presence of either LPA or S1P. Interestingly, siRNA targeting of Cdc42 only inhibited S1P-induced invasion (Fig. 5A). Efficiency and specificity of siRNA transfection was assessed by Western blotting (Fig. 5B). These data indicate that Rac1 and Cdc42 are important GPCRs involved in lipid-induced invasion in our system. Furthermore, Rac1 is involved in both LPA and S1P-induced invasion of 3D collagen matrices, while Cdc42 appears to be required only for S1P-induced invasion.

\section{MMPs are required for lipid agonist-induced tumor cell motility in 3D collagen matrices but not on 2D collagen substrates}

Previous reports have indicated that tumor cell motility in $3 \mathrm{D}$ matrices can occur in the absence of proteolysis (MMPs) [3,49], and that in some cases, MMPs are necessary for motility on 2D substrates [50,51]. Therefore using additional assays, we investigated whether lipid agonistinduced motility and/or invasion of 3D collagen matrices required MMPs. In modified Boyden chambers, the addition of the synthetic MMP inhibitors GM6001, Tumor- necrosis-factor- $\alpha$ protease inhibitor (TAPI)- 0 , and TAPI- 1 had no effect on HT1080 migration (Fig. 6). To compare 2D vs. 3D motility, the lipid-induced motility of HT1080 cells stably expressing nuclear GFP (Nuc-GFP HT1080) in 2D or 3D was assessed (Fig. 7). Briefly, Nuc-GFP HT1080 cells were either seeded on top of plastic dishes coated with $50 \mu \mathrm{g} / \mathrm{ml}$ of collagen (2D) or embedded and polymerized within a $3.75 \mathrm{mg} / \mathrm{ml}$ collagen gel (3D). Cells were tracked using time-lapse fluorescence microscopy, and data was analyzed using Metamorph ${ }^{\oplus}$ software.

Metamorph ${ }^{\oplus}$ generated tracings (lines) by tracking nuclear movement of individual cells over 24 hours (see methods and figure legends for additional details). In 2D, the same distances $(\sim 300 \mu \mathrm{m})$ and velocities $(\sim 0.21 \mu \mathrm{m} / \mathrm{min})$ of migration were noted regardless of the treatment (DMEM vs. LPA vs. S1P; One-way ANOVA: $p=0.767$ ). The addition of GM6001 only slightly decreased (DMEM) or increased (S1P) the distances $(\sim 277 \mu \mathrm{m}$ and $\sim 322 \mu \mathrm{m})$ and velocities of migration $(0.019 \mu \mathrm{m} / \mathrm{min}$ and 0.023 $\mu \mathrm{m} / \mathrm{min}$; One-way ANOVA: $\mathrm{p}<0.01$; Fig. 8 and Table 2; see additional file 3 and 4: 2D LPA and 2D LPA+GM6001 to view the time-lapse imaging of LPA-induced 2D motility with and without GM6001, respectively). However, when distances and velocities of cells embedded within a $3.75 \mathrm{mg} / \mathrm{ml}$ 3D collagen matrix were assessed, the lipid treatment and the addition of GM6001 had marked effects. In the presence of either LPA or S1P cells invaded $\sim 50 \mu \mathrm{m}$ further $(\sim 125 \mu \mathrm{m}$ vs. $\sim 75 \mu \mathrm{m}$ - t-test $\mathrm{p}<0.01$ for both) and reached a velocity $\sim 70 \%$ greater $(0.085 \mu \mathrm{m} /$ min vs. $\sim 0.050 \mu \mathrm{m} / \mathrm{min}-\mathrm{t}$-test $\mathrm{p}<0.01$ for both; see Table 2) compared to invasion with no lipid (DMEM). In the presence of DMEM, LPA, or S1P with GM6001 added to the culture media, the distance $(\sim 45 \mu \mathrm{m})$ and velocity $(0.030 \mu \mathrm{m} / \mathrm{min})$ of the invading cells was markedly decreased (t-test $\mathrm{p}<0.01)$ compared to treatment with DMEM or the lipid alone (Fig. 8; additional file 5 and 6 : 3D LPA and 3D LPA+GM6001 to view the time-lapse imaging of LPA-induced invasion of cells embedded in 

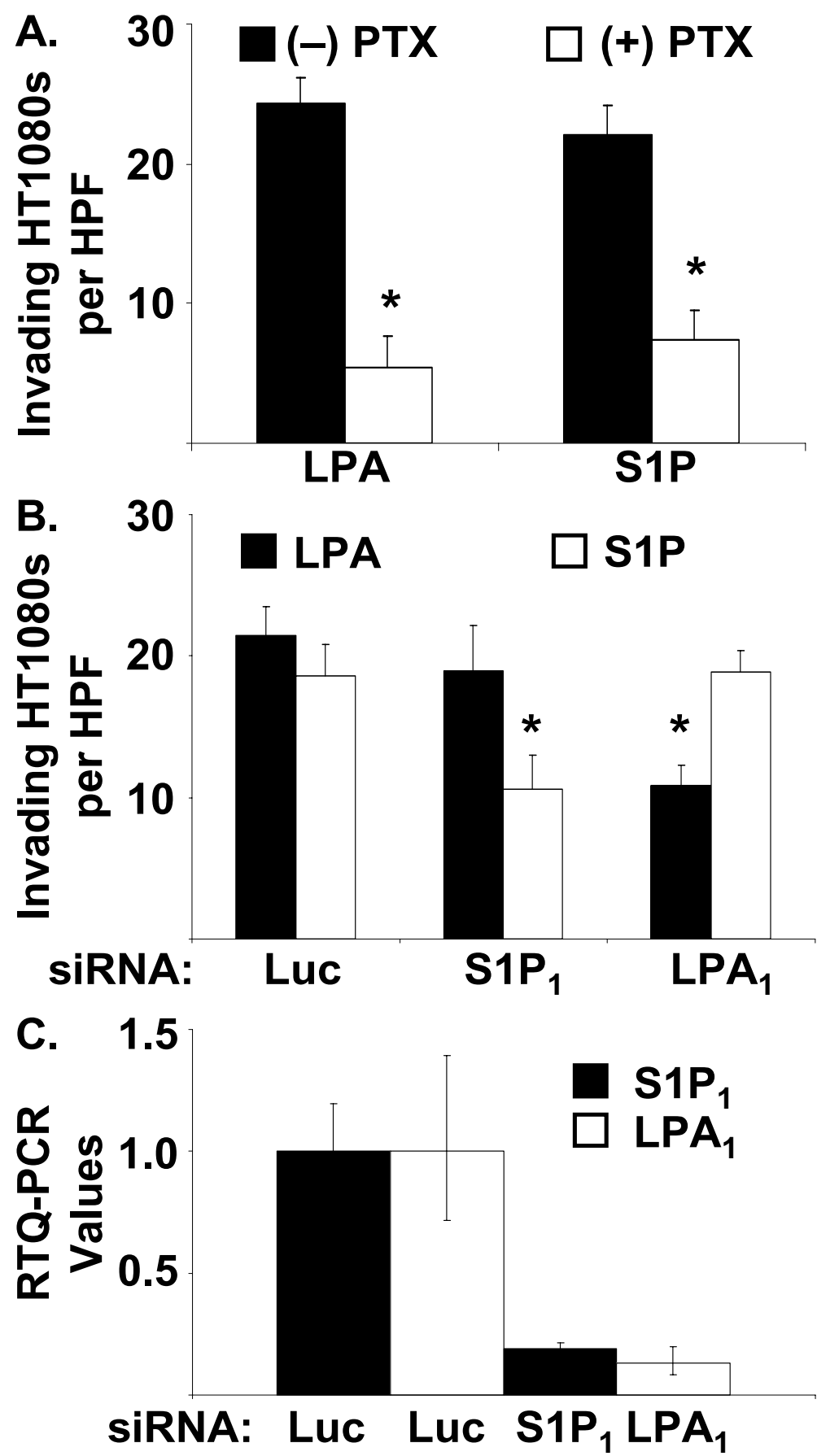

Figure 4

LPA, and SIP, regulate HTI 080 invasion of 3D collagen matrices in response to LPA and SIP, respectively. (A) HTI080 cells were allowed to invade in the presence of either LPA or SIP (I $\mu M)$ in the presence $(+)$ or absence $(-)$ of I00 ng/ $\mu \mathrm{l}$ of pertussis toxin (PTX). Cells were fixed, stained, and quantitated as described in Fig. 2. (B) HTI080 cells were transfected with siRNAs targeting the indicated genes and allowed to invade in the presence of either LPA or SIP (I $\mu M)$. Data are reported as mean numbers of invading cells per HPF $(20 \times)( \pm$ S.D.) from a minimum of 20 fields. Statistical significance of means was determined using t-test where $*=p<0.01$ relative to Luciferase (Luc) control for each lipid. (C) Real-time Quantitative PCR (RTQ-PCR) values for $L P A$, and SIP, mRNA normalized against I 8S RNA were used to illustrate selective targeting of the designated siRNA. 


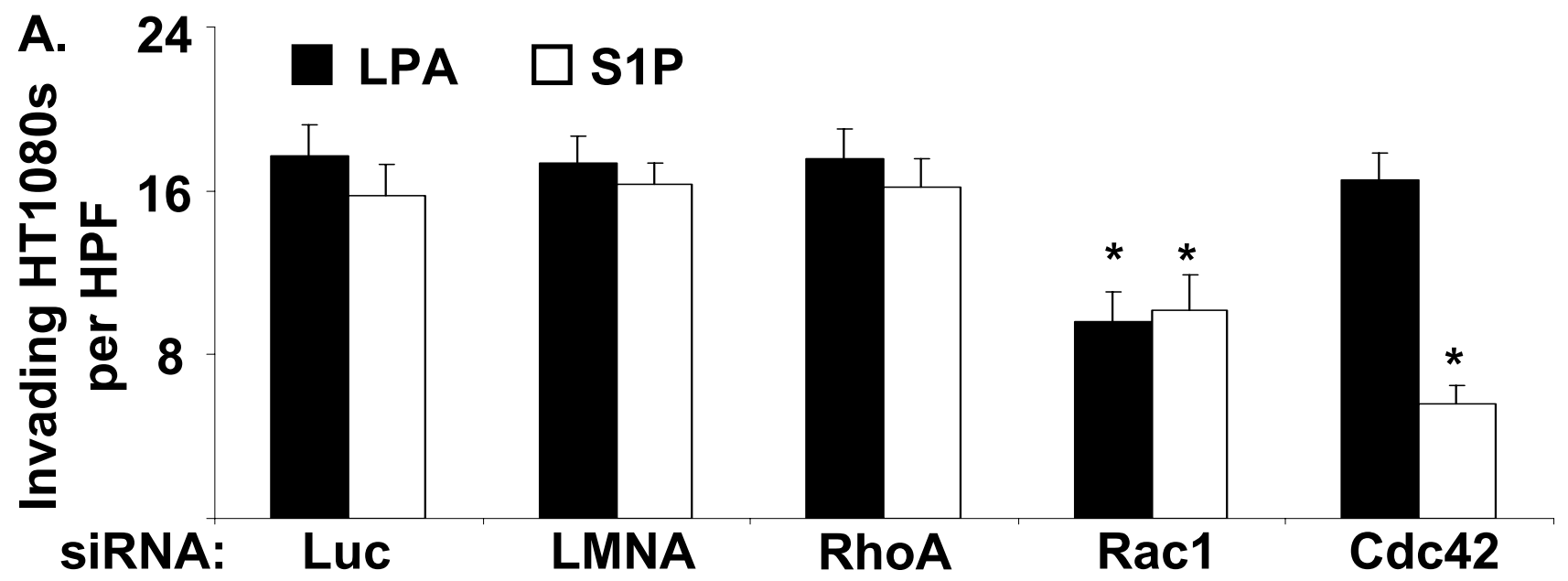

B.

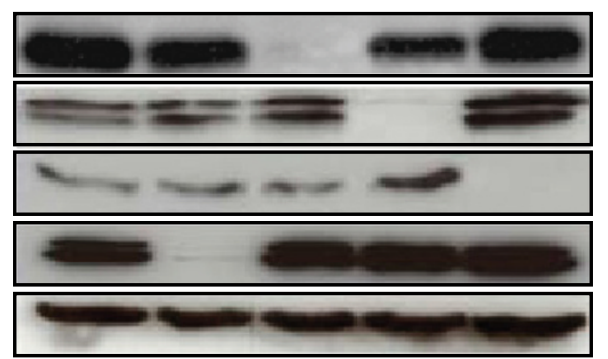

Antibody (kDa)

RhoA (21)

Rac1 (21)

Cdc42 (22)

Lamin A/C (65/70)

$\beta$-Actin (43)

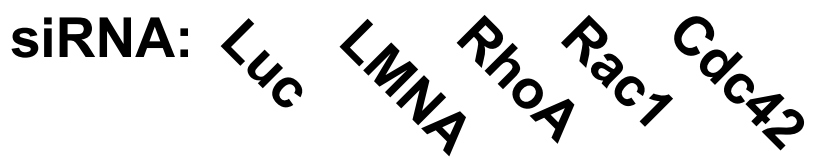

Figure 5

Racl and Cdc42 are downstream effectors involved in LPA- and SIP-induced HTI 080 invasion of 3D collagen matrices. (A) HTI080 cells were transfected with siRNAs targeting the genes indicated and allowed to invade in the presence either LPA or SIP $(I \mu M)$. Data are expressed as mean numbers of invading cells per HPF $(20 \times)$ ( \pm S.D.) from a minimum of 20 fields. Statistical significance of means was determined using t-test where $*=p<0.01$ relative to Luciferase (Luc) control for each lipid. LMNA = Lamin A/C. (B) siRNA transfected HTI080 cell lysates were prepared for Western blot analysis. Lysates were probed for Lamin A/C, RhoA, Racl, and Cdc42 to demonstrate siRNA specificity and probed for Actin as a loading control.

3D with and without GM6001, respectively). Together, these data demonstrate that lipid-induced invasion of 3D collagen matrices is a distinct process from lipid-induced migration through chemotactic chambers or on $2 \mathrm{D}$ substrata. In our assays, lipid-induced tumor cell invasion of $3 \mathrm{D}$ collagen barriers requires MMPs, whereas migration in $2 \mathrm{D}$ does not. Furthermore, these data demonstrate the marked ability of lipid agonists to induce tumor cell invasion of $3 \mathrm{D}$ collagen matrices, and that this invasion requires MMP activity.
MTI-MMP is a key proteinase required for lipid-induced tumor cell invasion of $3 D$ collagen matrices

Invasion of HT1080s in A/2 invasion assays in the presence of either LPA or S1P was abolished by adding $5 \mu \mathrm{M}$ of either GM6001, TAPI-0, or TAPI-1 to the culture media (Fig. 9A, B and data not shown). Likewise, adding $5 \mu \mathrm{M}$ of either GM6001, TAPI-0, or TAPI-1 to the culture media blocked LPA-induced A2058 melanoma invasion (data not shown) further corroborating that lipid-induced tumor cell invasion is an MMP-dependent event. However, synthetic inhibitors of MMPs such as GM6001 lack specificity and inhibit a broad range of metalloproteinases. To identify the predominant class of MMPs involved in lipid-induced invasion of HT1080 cells, recombinant 


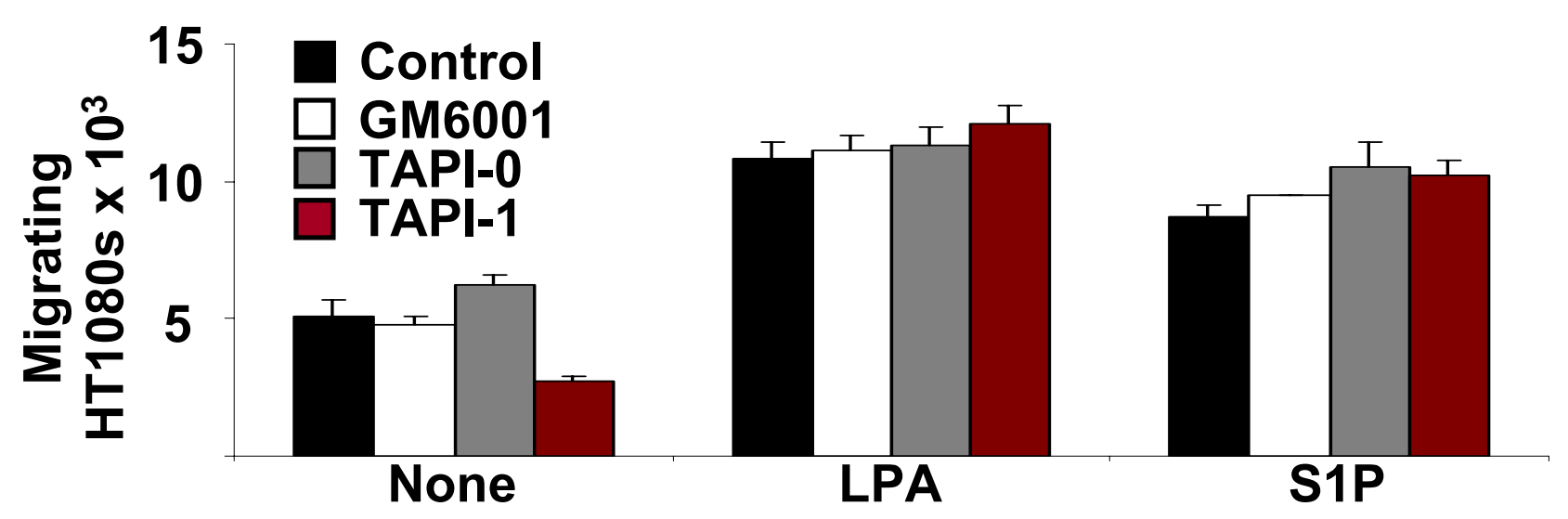

Figure 6

HTI 080 cell motility using modified Boyden chambers does not require MMPs. HTI080 cells were seeded onto porous $(8 \mu \mathrm{m})$ polycarbonate membranes coated with type I collagen $(\mathrm{I} \mathrm{mg} / \mathrm{ml})$ and allowed to migrate for four hours in the presence of I $\mu$ M LPA or SIP in the presence or absence of synthetic MMP inhibitors ( $5 \mu$ M GM600I, $5 \mu$ M TAPI-0, or $5 \mu$ M TAPI-I). Membranes were removed, stained, and migrating cells were quantitated using Scion ${ }^{\circledR}$ software and Microsoft Excel ${ }^{\circledR}$. Data are expressed as mean number of migrating cells $\times 10^{3}( \pm$ S.D.) and represent the results of quadruplicate experiments.

TIMP-1, $-2,-3$, or -4 were added to $\mathrm{A} / 2$ invasion assays at $5 \mu \mathrm{g} / \mathrm{ml}$ (Fig. 9A) TIMPs exhibit specificity for differing classes of metalloproteinases [soluble MMPs versus membrane-type MMPs and the ADAM ( loproteinase)] family of metalloproteinases [52,53]. Therefore, we used this property of the TIMPs to identify the particular class(es) of proteinase(s) involved in lipidinduced invasion of HT1080 cells. TIMP-2, -3, and -4, which are molecules known to inhibit both soluble, ADAMs, and membrane-type MMPs, each blocked lipidinduced invasion of HT1080 cells (Fig. 9A, B). The addition of TIMP-1, a TIMP capable of inhibiting soluble but not membrane-type MMPs, had no effect on lipidinduced HT1080 invasion. Analogous findings with TIMPs were seen in time course experiments using the side-view invasion system (See additional file 7: LPA+TIMP-1 to view the time-lapse imaging of LPAinduced HT1080 invasion in the presence of TIMP-1 and additional file 8: LPA+TIMP-3 to view the time-lapse imaging of LPA-induced HT1080 invasion in the presence of TIMP-3). These results indicate a requirement for membrane-bound MMPs in lipid-induced HT1080 invasion of $3 \mathrm{D}$ collagen matrices.

We next evaluated the intriguing observation that although SKOV3 and HEK293 cells markedly migrated in response to LPA in Boyden chamber assays, these cell lines were unable to invade $3 \mathrm{D}$ collagen matrices in response to these lipids as noted previously (Fig. 1 and Fig. 2B). Western blot analysis was performed to characterize endogenous MT1-MMP levels of the four tumor cell types (Fig. 10A). Remarkably, the level of MT1-MMP expression directly correlated with the ability of the tumor cell lines to invade $3 \mathrm{D}$ collagen matrices.

To investigate further the role of MT1-MMP in LPAinduced invasion, HEK293 cells (which do not invade in response to LPA) were transfected with MT1-MMP cDNA and allowed to invade in response to LPA for 48 hours. Once transfected, HEK293 cells invaded in the presence of LPA (Fig. 10B). Transfection with a control plasmid (pAdTrack-CMV), or plasmids encoding human MT2MMP or MT3-MMP did not induce invasion despite appropriate expression of the various proteins (Fig. 10C). These data illustrate that MT1-MMP is required for LPAinduced invasion of HEK293 cells. The HEK293 cells also represent an interesting new model to assess tumor cell invasion due to their inability to invade unless genes such as MT1-MMP are supplied by transfection.

Next, we evaluated the role of MT1-MMP in lipid-induced invasion of HT1080 cells using the A/2 invasion assay. HT1080 cells were transfected with siRNAs targeting either the membrane-type MT1-, MT2-, or MT3-MMPs, soluble MMP-2 or MMP-9, or control siRNAs (scrambled MT1-MMP, Lamin A/C, or Luciferase GL2 duplex) prior to initiation of invasion assays. Transfection with either custom or SMARTpool ${ }^{\circledR}$ siRNAs targeting MT1-MMP were capable of inhibiting MT1-MMP protein expression on Western blot (Fig. 11A), pro-MMP-2 activation on gelatin zymography (Fig. 11B), and tumor cell invasion of 3D collagen matrices in response to either LPA or S1P (Fig. 12A, B). Transfection of HT1080 cells with siRNAs targeting the soluble MMPs (MMP-2 or MMP-9) or control siRNAs (Lamin A/C or Luciferase) had no influence on 

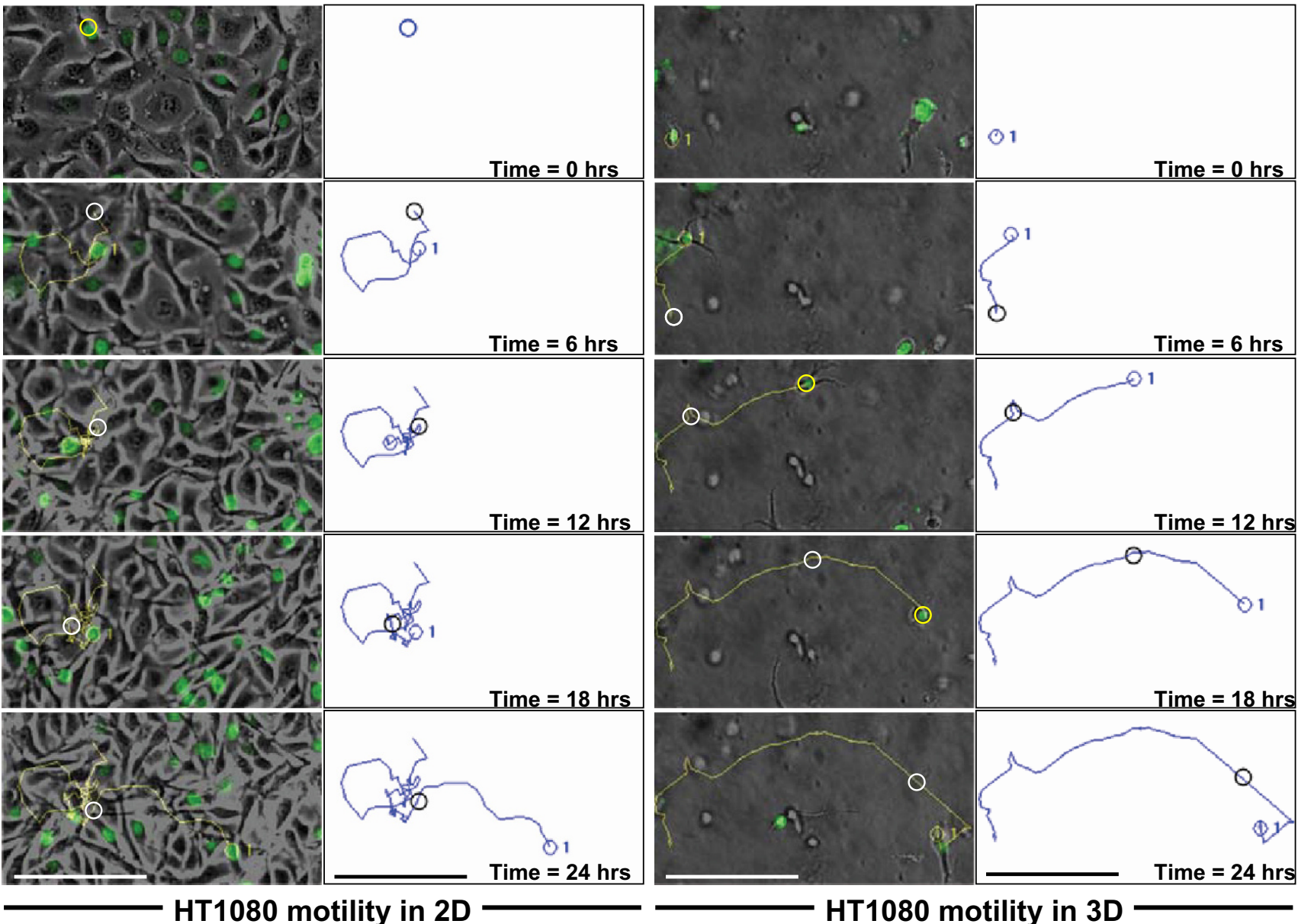

Figure 7

Time-lapse assessment of lipid agonist-induced HT 1080 cell motility on 2D collagen substrates versus 3D collagen matrices. Nuc-GFP HTI 080 cells were seeded on 2D plastic dishes coated with $50 \mu \mathrm{g} / \mathrm{ml}$ of collagen or embedded within a $3.75 \mathrm{mg} / \mathrm{ml}$ type I collagen matrix and their motility was analyzed using Metamorph ${ }^{\circledR}$ software. Digital fluorescent images were acquired every 15 minutes and arranged in sequential order. A single cell is shown either moving on top of a dish (2D) or through $3.75 \mathrm{mg} / \mathrm{ml}$ collagen matrix (embedded in 3D) at 6 hour intervals for 24 hours. Tracings (generated by Metamorph $^{\circledR}$ ) of the continuous movement of these cells over the 24 hour time period are shown by the blue lines. (Note: Metamorph ${ }^{\circledR}$ creates a yellow line on a black background which is difficult to see. Therefore, the images were inverted to turn the yellow line blue and the black background white.) A blue (yellow) circle indicates the current position of the cell and a black (white) circle indicates the previous position. Subsequent tracings were converted to grayscale. Magnification $=20 \times$. Scale bars $=50 \mu \mathrm{m}$.

invasion (Fig. 12A, B). Similarly, invasion time course experiments revealed that HT1080 cells transfected with MT1-MMP siRNA exhibited nearly a 3-fold slower rate of invasion ( $\sim 5 \mathrm{~m} / \mathrm{hr}$ vs. $\sim 14 \mu \mathrm{m} / \mathrm{hr}$ for MT1-MMP and Luciferase, respectively) and decreased distance of invasion ( $200 \mu \mathrm{m}$ vs. $\sim 700 \mu \mathrm{m})$ compared to Luciferase or scrambled MT1-MMP controls (Fig. 13A-D and Table 1). Collectively, our data identifies MT1-MMP as a key proteinase involved in lipid agonist-induced signaling and tumor cell invasion of 3D collagen matrices.
MTI-MMP is required for lipid-induced invasion of tumor cells embedded within $3 D$ collagen matrices

Cells embedded within 3D collagen matrices can exhibit altered cellular behavior compared to cells cultured on the surface of collagen matrices $[5,54,55]$. Therefore, the role of MT1-MMP in lipid-induced invasion of HT1080 cells embedded within $3.75 \mathrm{mg} / \mathrm{ml}$ 3D collagen was assessed (as described in Figure 7). Nuc-GFP HT1080 cells were transfected with siRNAs targeting MT1-MMP (custom) or Luciferase (control) prior to initiation of the assays. Cell 

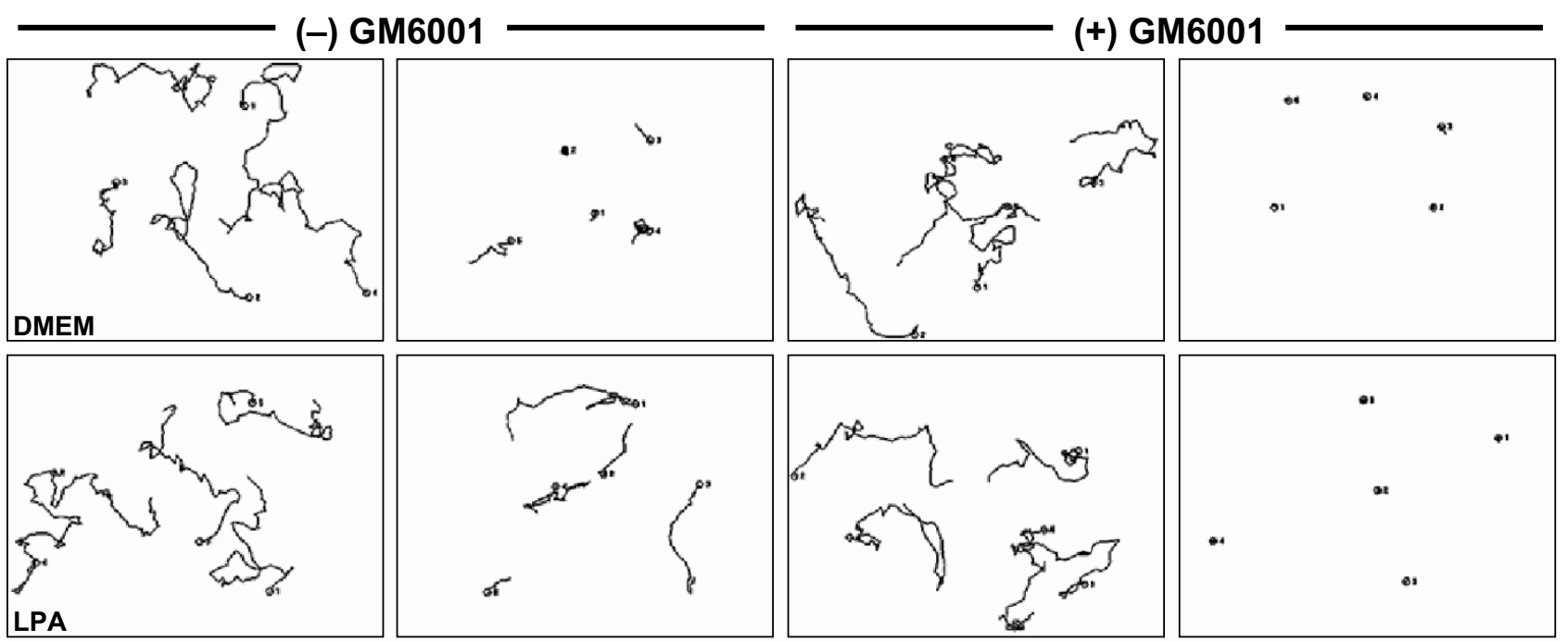

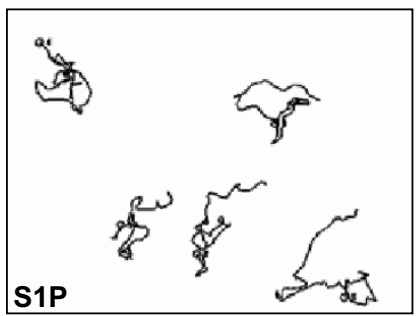

2D Tracings

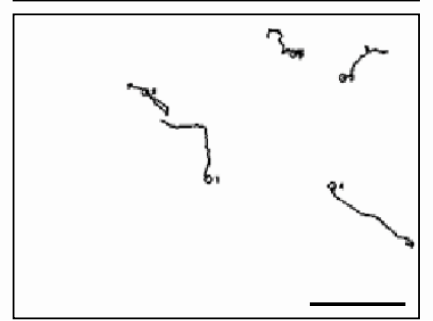

3D Tracings

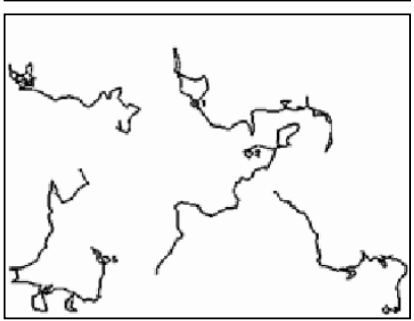

2D Tracings

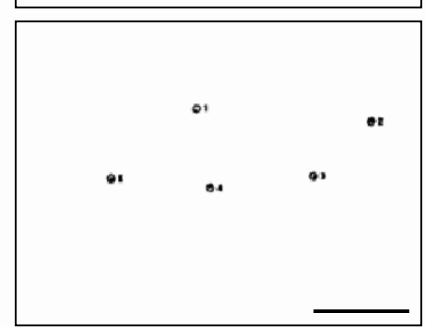

3D Tracings

\section{Figure 8}

Lipid agonist-induced tumor cell motility requires MMPs in 3D collagen matrices but not on 2D collagen substrates. Five individual cell tracings generated by Metamorph ${ }^{\circledR}$ (grayscale) in the presence of the specified lipid with or without $5 \mu$ M GM600I (see Table 2 for distance and velocity calculations). Magnification $=20 \times$. Scale bars $=100 \mu \mathrm{m}$.

nuclei were tracked in 3D matrices as illustrated in Figure 7. Representative 24 hour tracings of nuclear movements are presented (Fig. 14). Cells transfected with custom
MT1-MMP siRNA exhibited both decreased distance $(\sim 138 \mu \mathrm{m}$ vs. $\sim 90 \mu \mathrm{m}-$ t-test $\mathrm{p}<0.01)$ and velocity $(\sim 0.096 \mu \mathrm{m} / \mathrm{min}$ vs. $\sim 0.064 \mu \mathrm{m} / \mathrm{min}-$ t-test $\mathrm{p}<0.01)$ of

Table 2: The synthetic MMP inhibitor GM600 I decreases distance and reduces velocity of lipid-induced HT 1080 motility in 3D collagen matrices but not on 2D collagen substrates.

\begin{tabular}{ccccc}
\hline $\begin{array}{c}\text { Condition (over 24 } \\
\text { hours) }\end{array}$ & Avg. Distance $\mu \mathbf{m}$ (2D) & Avg. Distance $\mu \mathbf{m}$ (3D) & $\begin{array}{c}\text { Avg. Velocity } \mu \mathbf{m} / \mathbf{m i n} \\
\text { (2D) }\end{array}$ & $\begin{array}{c}\text { Avg. Velocity } \mu \mathbf{m} / \mathbf{m i n} \\
\text { (3D) }\end{array}$ \\
\hline DMEM & $303.68 \pm 71.1$ & $73.07 \pm 31.74$ & $0.21 \pm 0.049$ & $0.050 \pm 0.022$ \\
DMEM + GM600I & $277.38 \pm 29.38$ & $45.06 \pm 15.17$ & $0.19 \pm 0.020$ & $0.031 \pm 0.010$ \\
LPA & $298.58 \pm 41.18$ & $128.00 \pm 56.98$ & $0.21 \pm 0.029$ & $0.088 \pm 0.039$ \\
LPA + GM600I & $303.18 \pm 55.41$ & $40.43 \pm 6.08$ & $0.21 \pm 0.038$ & $0.028 \pm 0.0042$ \\
SIP & $303.05 \pm 33.78$ & $116.24 \pm 25.39$ & $0.21 \pm 0.028$ & $0.080 \pm 0.017$ \\
SIP + GM600I & $322.93 \pm 69.05$ & $44.598 \pm 9.25$ & $0.23 \pm 0.049$ & $0.031 \pm 0.0057$ \\
Luciferase* & N/A & $138.43 \pm 57.71$ & N/A & $0.096 \pm 0.040$ \\
si MTI-MMP* & N/A & $92.15 \pm 35.90$ & N/A & $0.064 \pm 0.025$
\end{tabular}

Nuc-GFP HTI080 cells were seeded on 2D plastic dishes coated with $50 \mu \mathrm{g} / \mathrm{ml}$ of collagen or embedded within a $3.75 \mathrm{mg} / \mathrm{ml}$ type I collagen matrix and their motility was analyzed using Metamorph ${ }^{\circledR}$ software (see Fig. 7) in the presence of the specified lipid with or without GM600I. siRNA (Luciferase or custom MTI-MMP) treated nuc-GFP HTI080 cells were only analyzed in 3D (see Fig. 14). Data are expressed as the average total distance $(\mu \mathrm{m})$ or average velocity $(\mu \mathrm{m} / \mathrm{min}) \pm$ S.D. of 15 tracings per condition. [Note: 96 distances and velocities (I44 for siRNA experiments) were generated per tracing for a total of I440 (2160) data points]. Statistical significance of means was determined using either One-way ANOVA or t-test where $\mathrm{p}<0.05$ was deemed statistically signficant (see text for specific comparisons). 


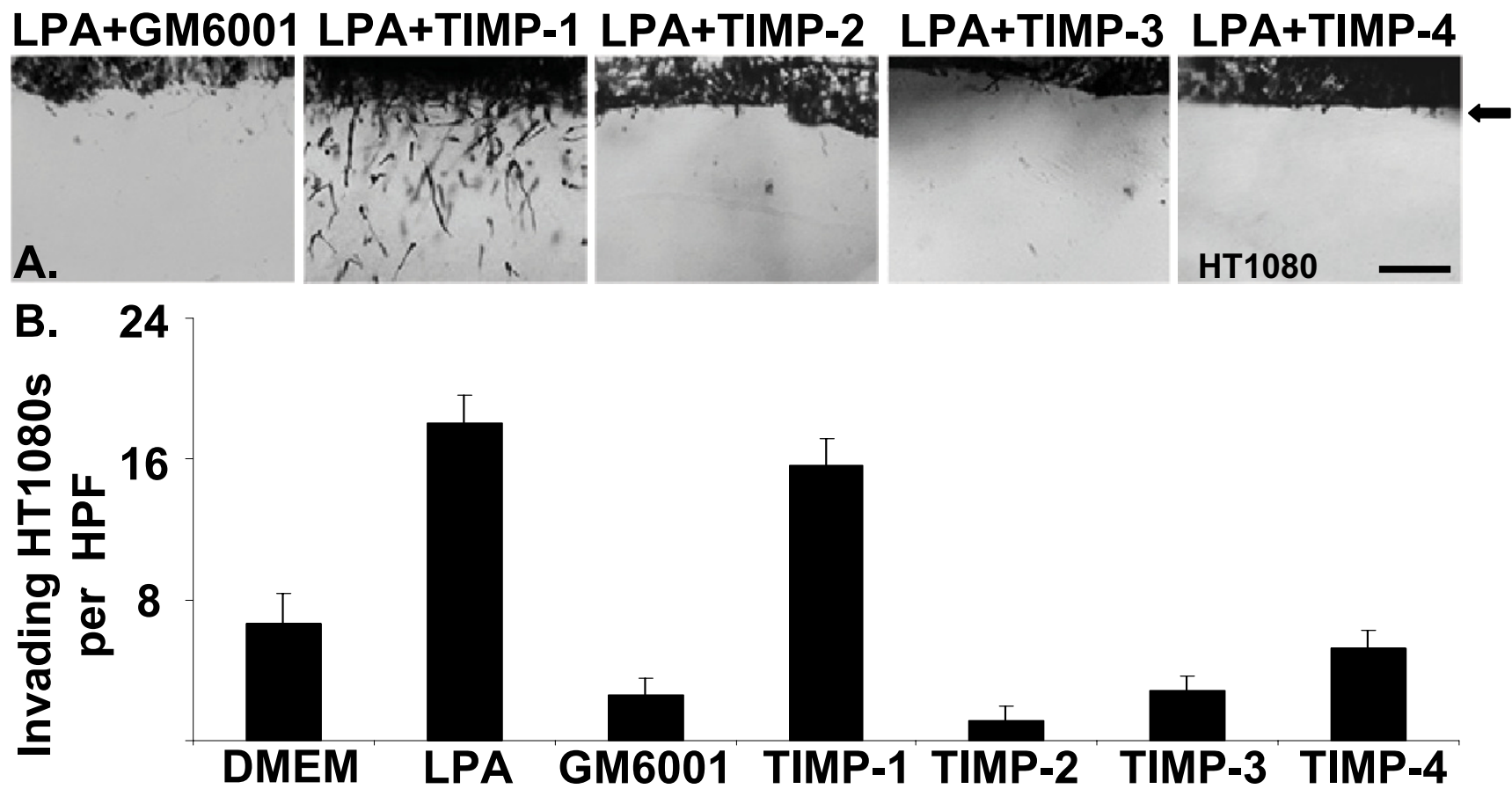

Figure 9

MT-MMPs are required for tumor cells to invade 3D collagen matrices. (A) HTI 080 cells were induced to invade 3D collagen gels $(3.75 \mathrm{mg} / \mathrm{ml})$ as in Fig. 2 in the presence of I $\mu$ M LPA and the synthetic MMP inhibitor GM600I (5 $\mu$ M), or TIMP$\mathrm{I},-2,-3$, or $-4(5 \mu \mathrm{g} / \mathrm{ml})$. Arrowheads indicate the position of the tumor cell monolayer at the initiation of invasion. Magnification $=20 \times$. Scale bar $=50 \mu \mathrm{m}$. (B) Quantitation of HTI080 invasion from panel A. Data are expressed as mean numbers of invading cells per HPF $(20 \times)$ ( \pm S.D.) from a minimum of 20 fields.

invasion in $3 \mathrm{D}$ collagen matrices in the presence of LPA (Fig. 14 and Table 2) similar to that observed when HT1080 cells were treated with $5 \mu \mathrm{M}$ GM6001 (Fig. 8 and Table 2). Additional experiments using $1 \mu \mathrm{M}$ S1P yielded similar results (data not shown). These data indicate that lipid-induced dissemination of individual tumor cells embedded in 3D collagen matrices also requires MT1MMP.

\section{Discussion \\ LPA and SIP are collaborative regulators of tumor cell migration and invasion}

LPA receptors are classic GPCRs, and have been shown to be abnormally expressed in cancer cells [25,27]. LPA is also elevated in the plasma of patients with ovarian carcinoma, indicating a link between LPA and early intraperitoneal dissemination $[24,56]$. Our data strongly indicate that LPA is a potent tumor cell motility factor when compared to other factors such as cytokines or chemokines. The recent discovery of autotaxin, an enzyme that generates LPA or S1P and is expressed by tumor cells, highlights the importance of LPA and S1P in tumor cell motility $[22,57,58]$. Intriguingly, our data suggest that LPA and
S1P exert opposing effects on most tumor cell types (Fig. 1). Previous studies establish that lipid agonist signaling pathways may be particularly important in this context [21,27,59-62]. By identifying differential receptors involved in LPA and S1P signaling (i.e. $\mathrm{LPA}_{1}$ and $\mathrm{S} 1 \mathrm{P}_{1}$ ) and the various downstream GTPase effectors (e.g. Rac1 and Cdc42), we hypothesize that motility and invasion are regulated by a balance between these pro- and antimigratory signals. Contrary to other tumor cell lines, HT1080 cells are not inhibited by S1P; in fact, S1P actually stimulates HT1080 migration and invasion (Figs. 1 and 2). This cell line is also one of the most invasive tumor types known $[41,42,63]$. Thus, the loss of S1P inhibition, or the ability of S1P to stimulate a tumor cell, may directly contribute to metastatic potential. Studies investigating the molecular differences in lipid signaling and their relevance to tumor cell invasion and metastasis in vivo are underway [64] and should be the subject of future work. 


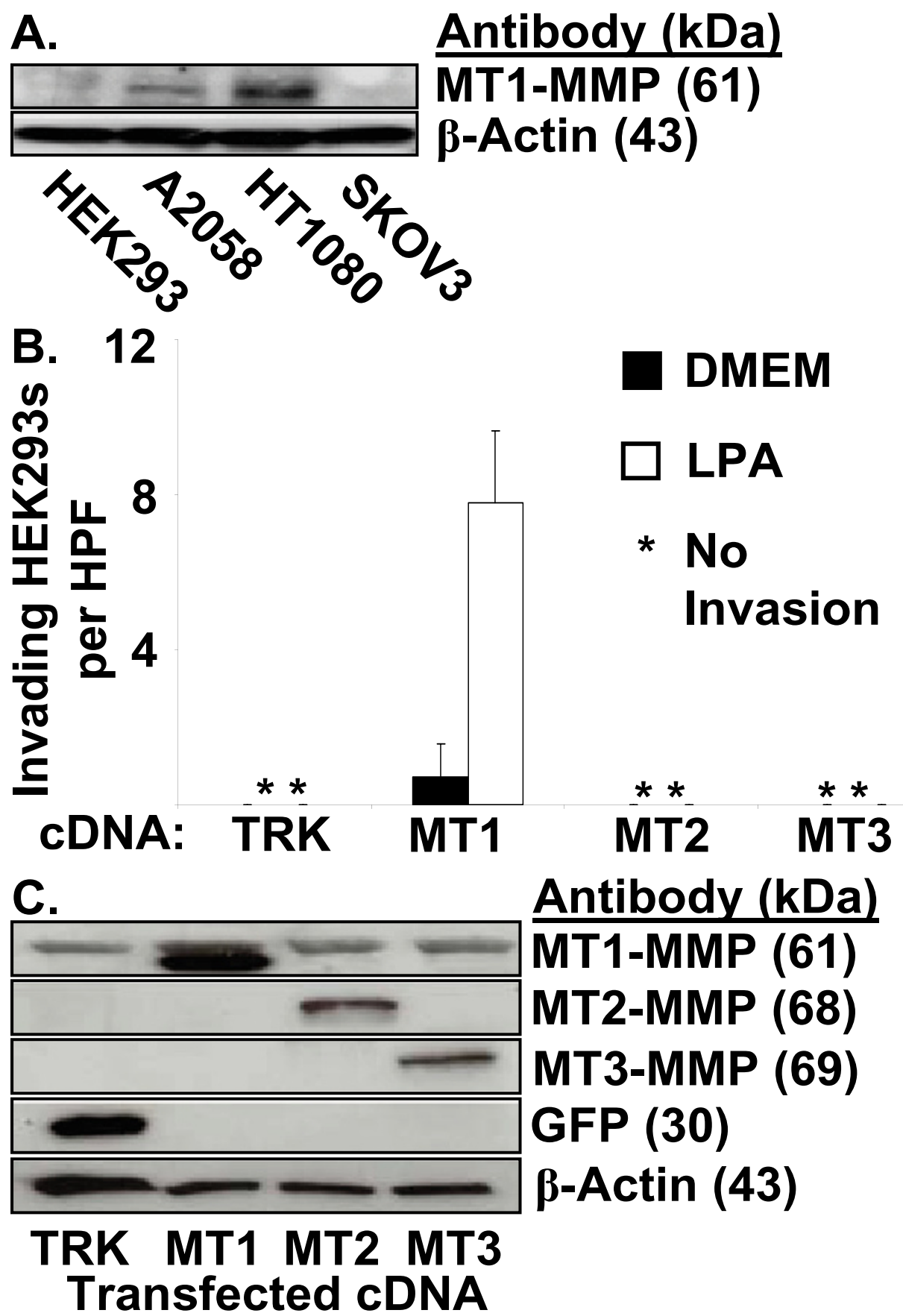

Figure 10

HEK293 cells transfected with MTI-MMP cDNA invade 3D collagen gels in response to LPA. (A) Tumor cell lysates were prepared for Western blot analysis. Lysates were probed for MT I-MMP to assess protein expression in the four tumor cell lines. Lysates were probed for Actin as a loading control. (B) HEK293 cells were transfected with the pAdTrackCMV plasmid as a control, or plasmids encoding MTI-MMP, MT2-MMP, or MT3-MMP cDNA 24 hours prior to placement in invasion assays. Cells were allowed to invade $2.0 \mathrm{mg} / \mathrm{ml}$ collagen gels in the presence or absence of I $\mu M$ LPA. Data are expressed as mean numbers of invading cells per HPF (20x) ( \pm S.D.) from a minimum of 20 fields. (C) Lysates from HEK 293 cells transfected with cDNAs encoding the designated genes were prepared for Western blot analysis and probed for GFP, MTI-MMP, MT2-MMP, MT3-MMP, or Actin as a loading control. TRK = pAdTrack-CMV, MTI = MTI-MMP, MT2 = MT2-MMP, MT3 = MT3-MMP. 

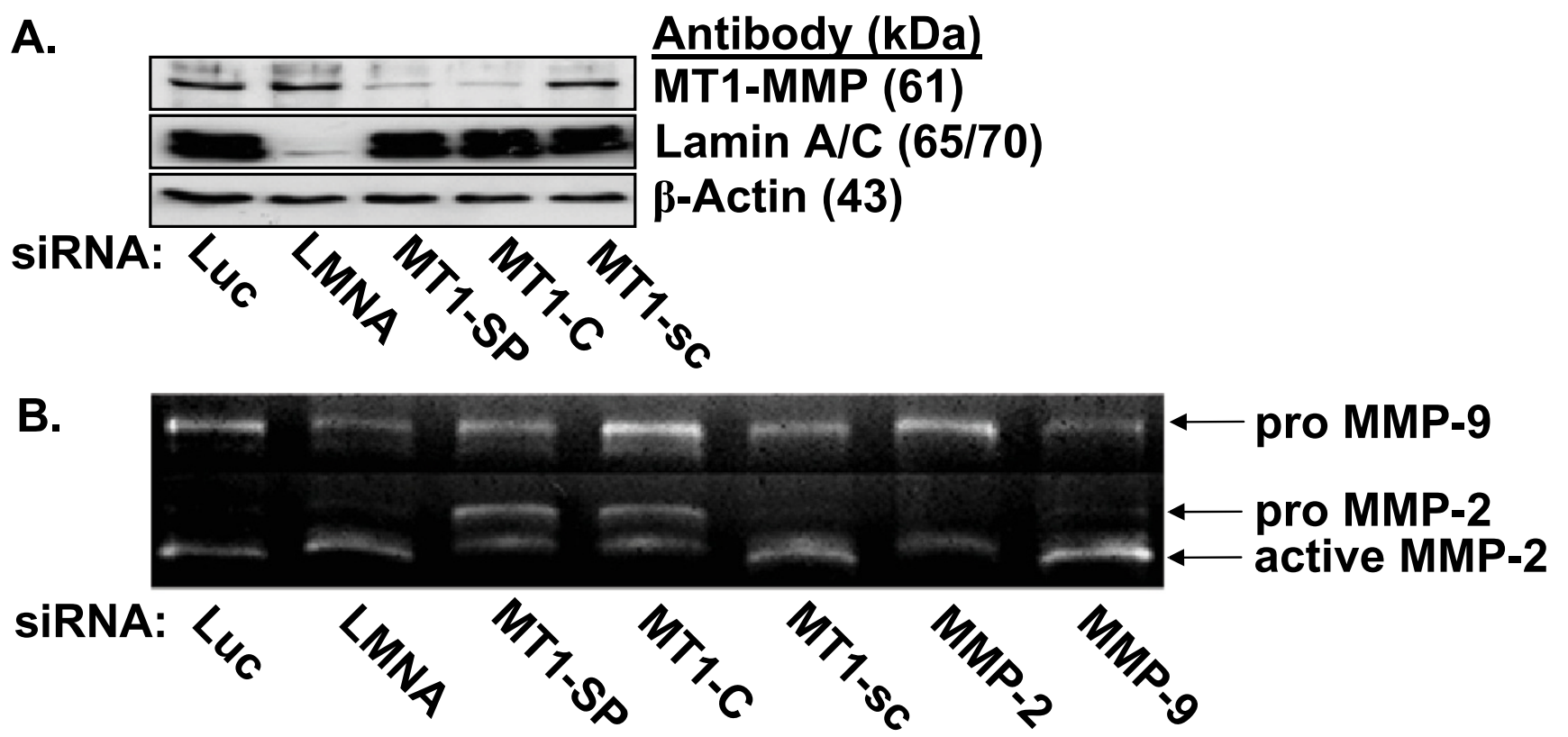

Figure I I

siRNAs targeting MTI-MMP reduce protein levels and MMP-2 activity on gelatin zymography. (A) Invading HTI080 cells lysates were prepared for Western blot analysis and probed for MTI-MMP and Lamin A/C to demonstrate siRNA efficiency and specificity. Actin was used as a loading control. (B) Conditioned media from siRNA-treated HTI080 cells were collected after 48 hours of invasion and gelatin zymography was performed. Arrows denote pro-MMP-9, and pro- and active forms of MMP-2.

\section{LPA and SIP regulate tumor cell invasion of 3D collagen matrices via MTI-MMP}

When invasion of tumor cells was assessed, we found that an ability to migrate in response to LPA did not necessarily confer an invasive phenotype in $3 \mathrm{D}$ collagen matrices. In fact, only a small subset of tumor cell lines screened in our models show strong invasive behavior (i.e. HT1080 cells). By far the majority of cell lines do not substantially invade in $3 \mathrm{D}$ collagen matrices under the conditions described in this report (Fisher and Davis, unpublished observations). One possible explanation for this result is that Western blot analysis revealed that non-invasive cell types (HEK293 or SKOV3) expressed low levels of MT1$\mathrm{MMP}$, a proteinase known to be involved in tumor cell invasion (Fig. 10A) [5,6,37]. When HEK293 cells were transfected with cDNA encoding MT1-MMP, cells were able to invade collagen matrices containing LPA (Fig. 9B). Using HT1080 cells, we were able to again distinguish MT1-MMP as a critical molecule involved in lipid-induced invasion using siRNA transfection targeting this proteinase (Figs. 12, 13, 14) or the addition of chemical or protein inhibitors of this proteinase (Fig. 9). A critical question that remains unanswered is the mechanism by which LPA stimulates MT1-MMP-dependent invasion of collagen matrices. One possibility is that LPA is involved in localizing or stabilizing MT1-MMP to critical areas of the cell surface required for matrix proteolysis during 3D locomotion.

The work presented here shows that LPA can both stimulate tumor cell motility on 2D substrates (Figs. 1, 6, and 8 ) and tumor cell invasion of 3D collagen matrices (Figs. $2,8,10$, and 12). Importantly, only the latter process depends on the MT1-MMP proteinase (Figs. 6, 8, 10, 14, and Table 2). Blockade of MT1-MMP using siRNA suppression or proteinase inhibitors strongly suppressed HT1080 movement in 3D collagen matrices and not on 2D collagen substrates. Also, HT1080 random cell motility on 2D substrates was not affected by LPA, while LPA clearly stimulated tumor cell movement/invasion in $3 \mathrm{D}$ collagen matrices. This data demonstrates that LPA strongly stimulates MT1-MMP-dependent tumor cell invasion behavior, and thus, is a critical co-factor along with matrix proteolysis in tumor cell invasion. An important unanswered question remains: how does LPA or S1P affect the ability of MT1-MMP to coordinate these invasive events? This central issue is fundamental to our understanding of how tumor and other cells such as endothelial cells invade 3D matrix environments. We hypothesize that LPA facilitates the localization of MT1MMP to specialized areas of the cell membrane that are necessary to drive tumor cell locomotion through $3 \mathrm{D}$ 

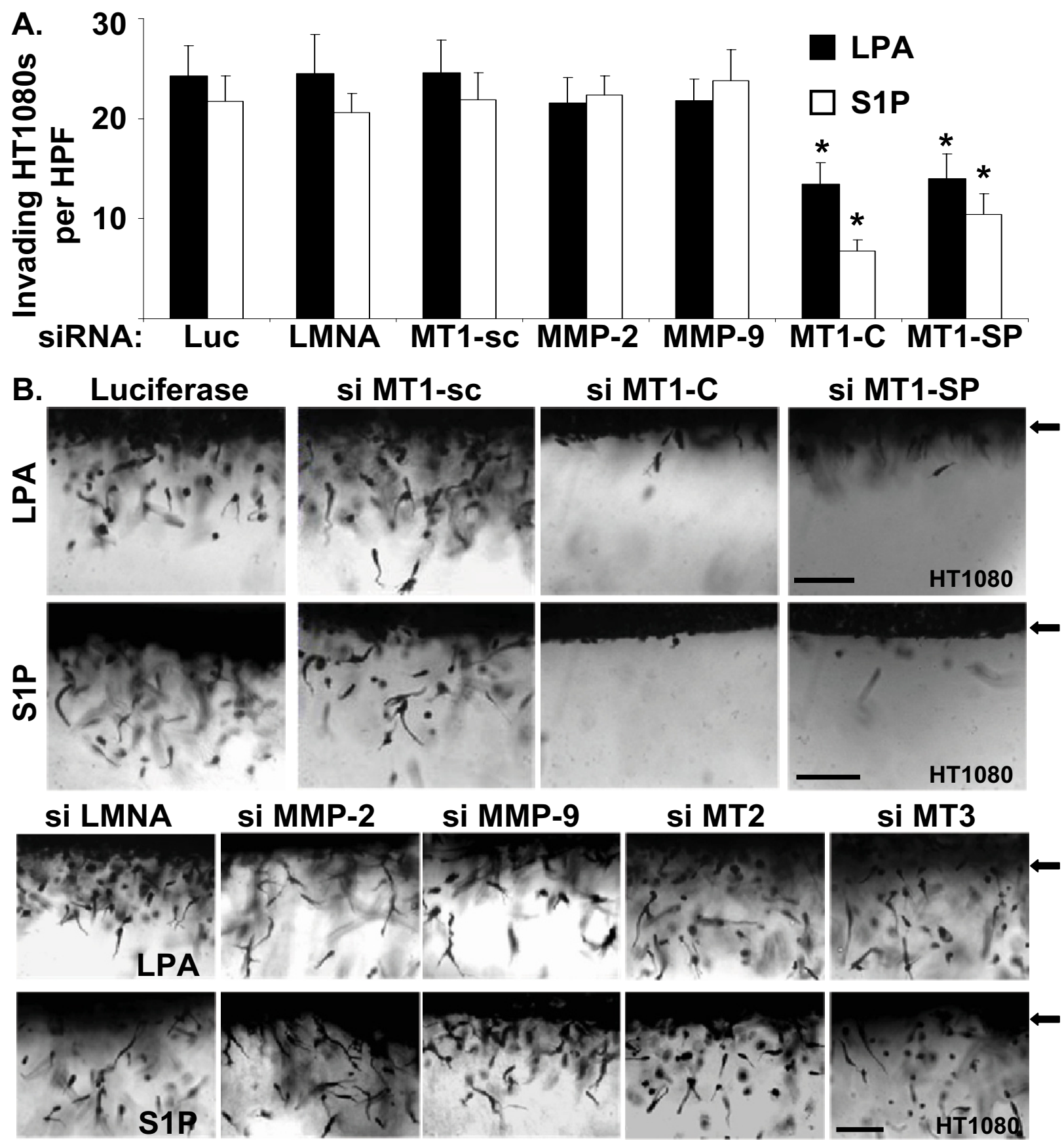

Figure 12

MTI-MMP is required for lipid-induced invasion of HTI 080 cells in 3D collagen gels. (A) HTI080 cells were transfected with control siRNAs (Luciferase, Lamin A/C, or a scrambled MTI-MMP), siRNAs targeting soluble MMP-2 or MMP-9, or siRNAs targeting MTI-MMP (MTI-C, MTI-SP). Cells were allowed to invade 3D collagen gels in response to LPA or SIP for 48 hours prior to fixation and quantification of invasion as in Fig. 2. Data are expressed as mean numbers of invading cells per HPF (20x) ( \pm S.D.) from a minimum of 20 fields per condition. Statistical significance of means was determined using t-test where $*=\mathrm{p}<0.01$ relative to Luciferase control. si $=$ siRNA; Luc $=$ Luciferase, LMNA $=$ Lamin A/C, MTI-C = custom MTIMMP, MTI-SP = SMARTpool ${ }^{\circledR}$ MTI-MMP, MTI-sc = scrambled MTI-MMP. (B) siRNA transfected HTI080 cells from panel A were imaged as in Fig. 2 to demonstrate tumor cell invasion. Magnification $=20 \times$. Scale bars $=50 \mu \mathrm{m}$. Arrowheads indicate the position of the monolayer at initiation of invasion. 

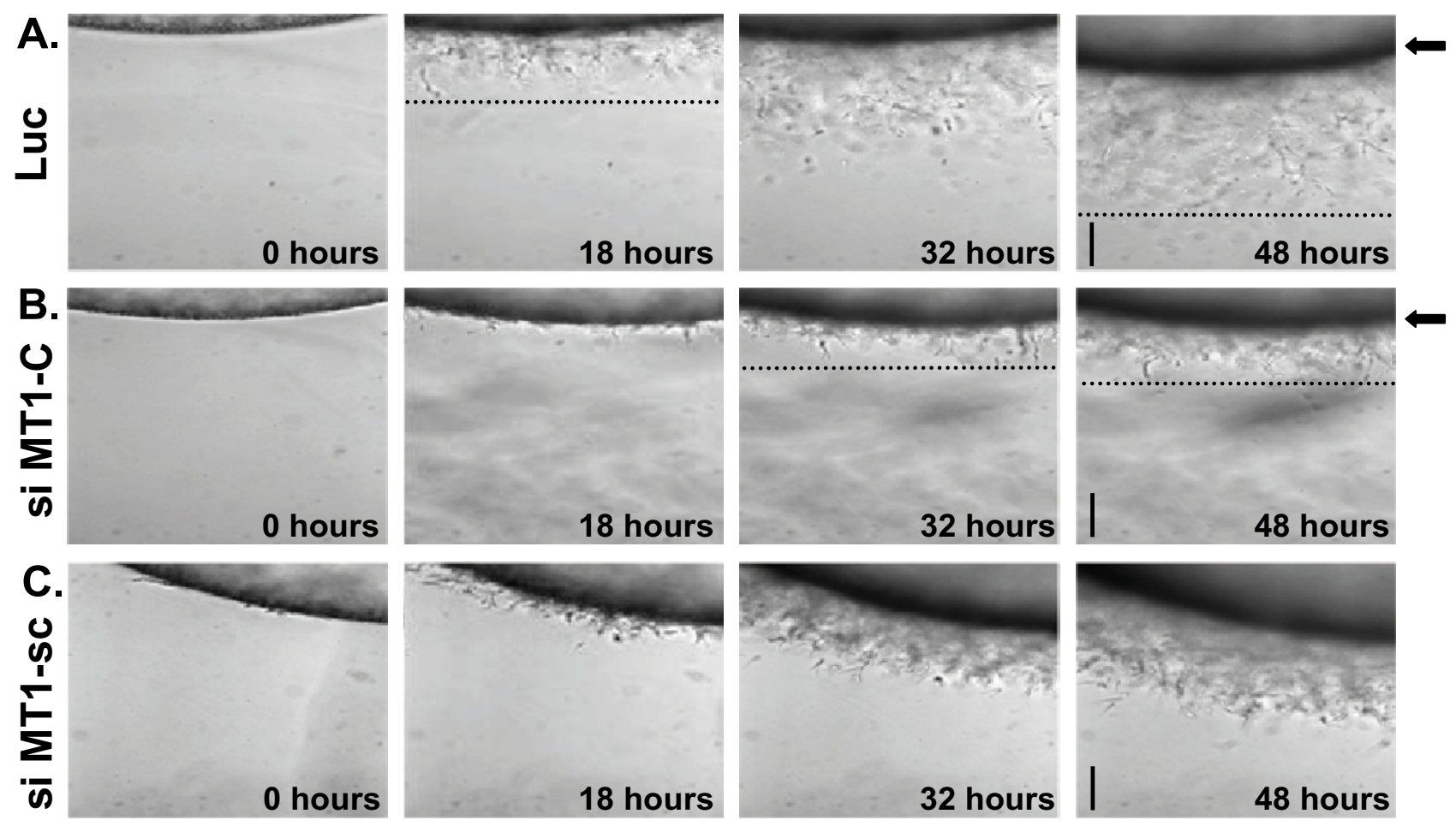

\section{800}

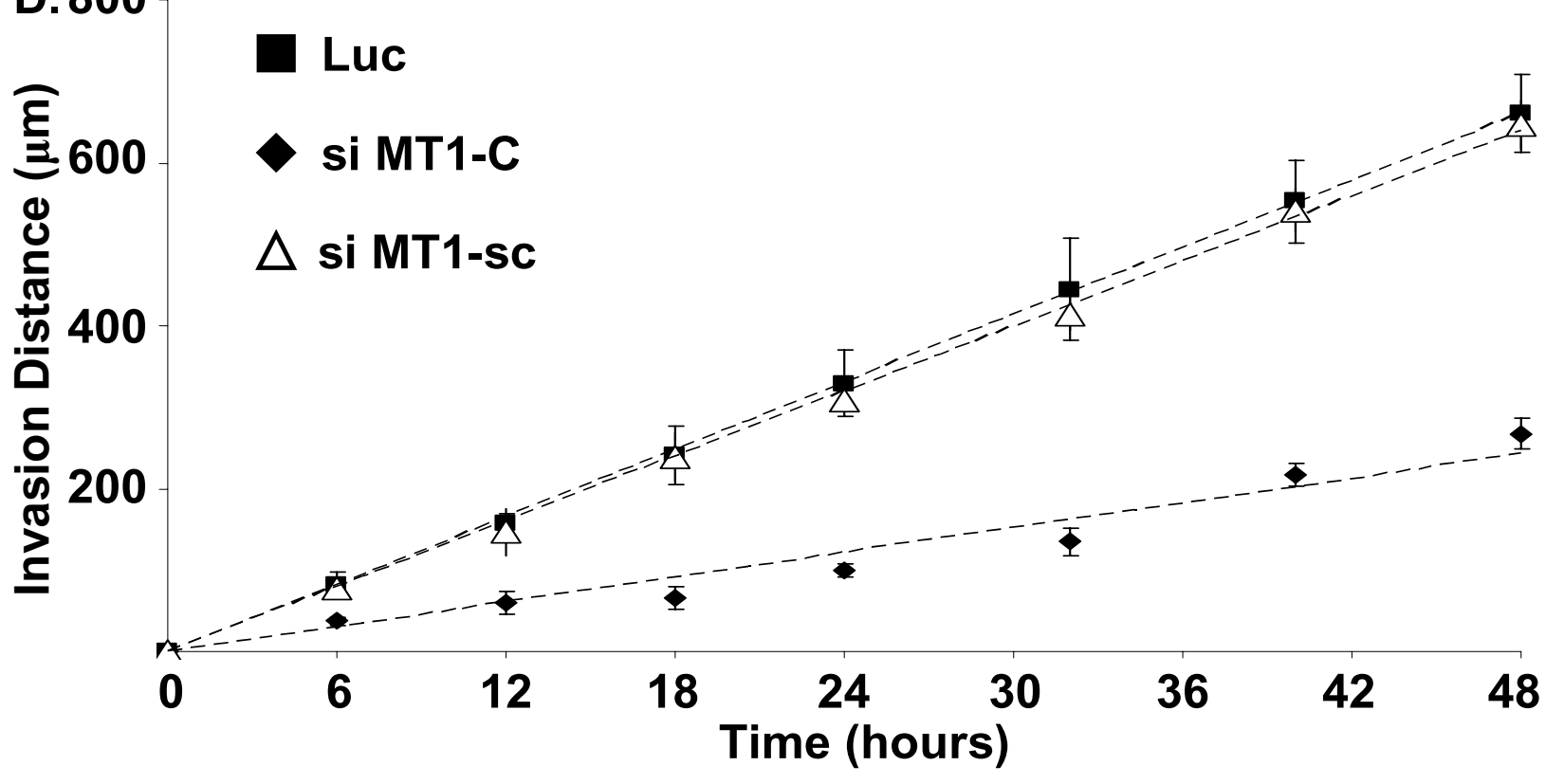

\section{Figure 13}

The rate of HTI 080 invasion is dependent on MTI-MMP. HTI080 cells transfected with siRNA targeting Luciferase (A), MTI-MMP (custom) (B), or scrambled MTI-MMP (C) were seeded onto $3.75 \mathrm{mg} / \mathrm{ml}$ collagen gels in glass casings (see methods for details) and allowed to invade for 48 hours in the presence I $\mu$ M LPA. Data were collected as in Fig. 3 and were plotted versus time (D). Rates of invasion were calculated using linear regression (see Table I). Data are expressed as mean rate of invasion ( $n=3$ wells, \pm S.D.) for each time point from triplicate experiments. Magnification $=10 \times$. Scale bars $=200 \mu \mathrm{m}$. Dashed line indicates front of tumor cell invasion. si = siRNA; Luc = Luciferase, MTI-C = custom MTI-MMP, MTI-sc = scrambled MTI-MMP. 
Luciferase

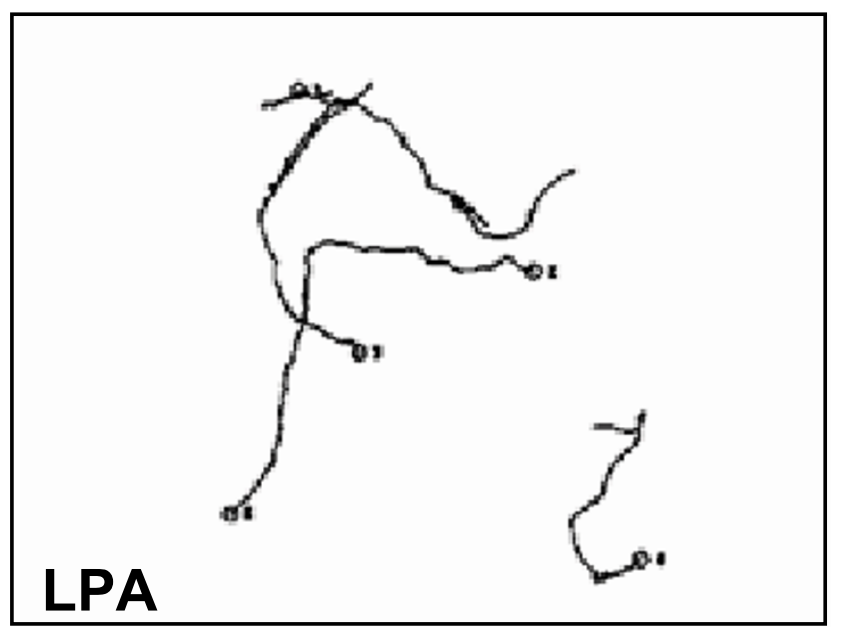

\section{D Tracings}

\section{Figure I4}

MTI-MMP is required for tumor cell movement when cells are embedded within 3D collagen matrices. Representative individual 24 hour tracings (illustrated in Fig. 7) of Luciferase or custom MTI-MMP siRNA transfected Nuc-GFP HTI080 cells embedded in 3D collagen matrices are presented (grayscale). Images were acquired every 10 minutes. Magnification $=20 \times$. Scale bars $=100 \mu \mathrm{m}$.

matrices. Other possibilities include that LPA stimulates the co-association of MT1-MMP with critical co-regulatory molecules such as collagen-binding integrins (e.g. $\alpha 2 \beta 1$, $\alpha 1 \beta 1, \alpha 10 \beta 1, \alpha 11 \beta 1)$. Preliminary experiments using siRNAs directed to MT1-MMP and the $\beta 1$ integrin subunit show that suppressing both of these genes at the same time completely inhibits HT1080 invasion of 3D collagen matrices (Fisher and Davis, unpublished observations).

Previous studies have implicated other MMPs (i.e. MMP2 and MMP-9) in tumor cell invasion and progression, and that LPA triggers upregulation or activation of MMP2 [24,63,65-67]. However, in our system, siRNAs targeting MMP-2 or -9 or other MT-MMPs did not influence tumor invasion of collagen matrices (Fig. 12). Our data indicate that MT1-MMP is the predominant proteinase involved in lipid-induced invasion of collagen matrices. These conclusions are similar to a recent study showing the selective ability of MT-MMPs to stimulate tumor invasion with no evidence presented for a role of soluble MMPs [5]. Additionally, MT1-MMP acts upstream and can activate MMP2. Thus, MT1-MMP appears to be the principle regulator of LPA-induced invasion. However, markedly decreasing levels of MT1-MMP via targeted siRNA transfection did not completely block completely invasion in HT1080 cells as effectively as the addition of GM6001 (Figs. 3, 8, and $12,13,14)$. In addition, the depth and numbers of si MT1-MMP
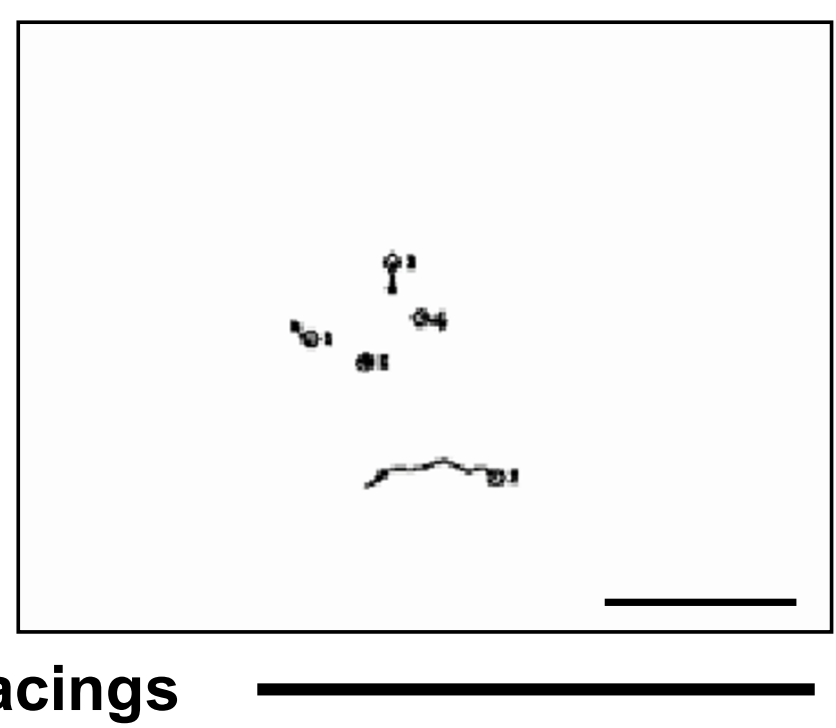

invading MT1-MMP-transfected HEK293 cells were not as extensive as seen in HT1080 cells (Fig. 10). These results may indicate a role for additional molecules (e.g. collagen-binding integrins or multiprotein complexes involving MT1-MMP) in our invasion system. It is also plausible that other cell surface expressed metalloproteinases (i.e. other MT-MMPs or ADAMs) could contribute to degradation of matrix components and host/tumor interactions (i.e. tumor-driven angiogenesis) not addressed here [63]. Additional studies are needed to identify and address the role of key complementary molecules in tumor invasion and how this relates to lipid-agonist induced invasion.

\section{Conclusion}

In this study, we demonstrated that LPA (and also S1P for HT1080s) stimulated the processes of motility and invasion through signaling of $\mathrm{LPA}_{1}, \mathrm{~S} 1 \mathrm{P}_{1}, \mathrm{Rac1}$, Cdc42, and MT1-MMP. In most tumor cell lines, LPA markedly stimulated tumor cell motility while S1P functioned as an inhibitor of migration (except for HT1080 cells). In 3D collagen invasion assays, the invasion of HT1080 and A2058 cell lines mimicked their migration profile. HEK293 and SKOV3 cells did not invade 3D collagen matrices, despite a marked ability to migrate in response to LPA. The $\mathrm{LPA}_{1}$ and S1P 1 GPCRs, along with Rac1 and Cdc42 were identified as crucial components of lipid agonist-induced invasion. Using our assays, we determined 


\section{Malignant Tumor Cells}

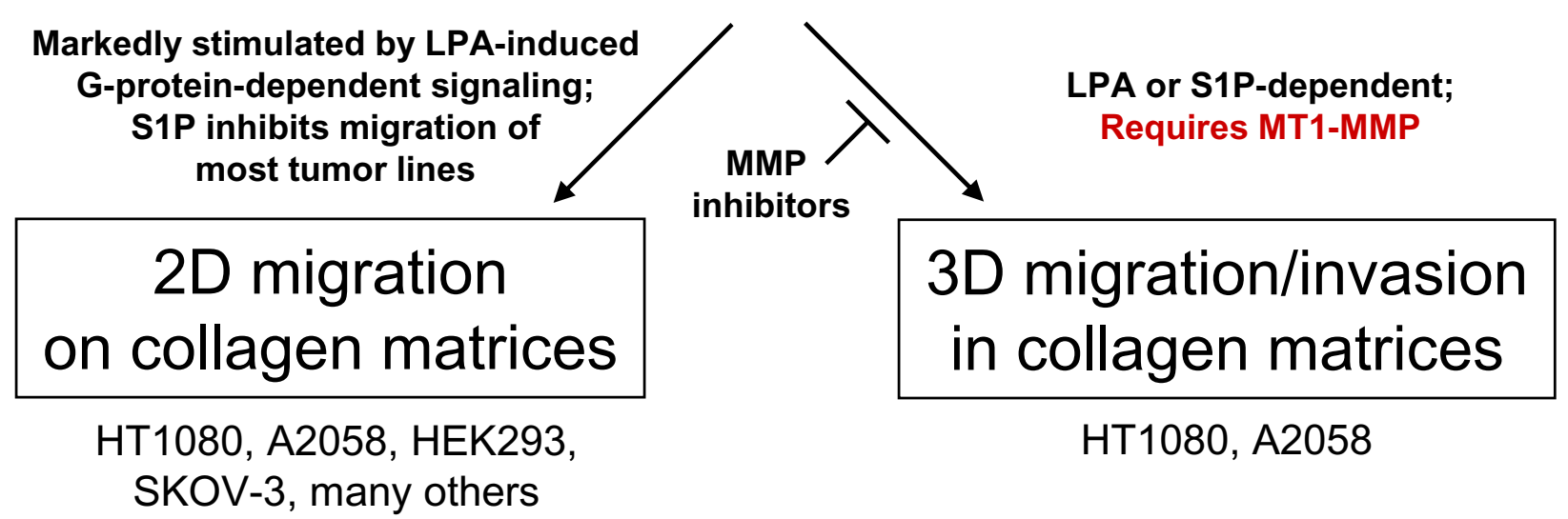

Figure I 5

Schematic diagram summarizing the roles of LPA, SIP, RhoGTPases, and MTI-MMP in tumor migration and invasion of collagen matrices. LPA stimulates tumor cells migration while SIP inhibits migration of most tumor types on 2D matrix substrates. Lipid-induced invasion of 3D collagen matrices, but not migration, requires MTI-MMP. Only tumor cell invasion of 3D matrices is blocked by MMP inhibitors.

that LPA-induced tumor cell invasion of 3D collagen matrices required proteolysis distinguishing it from lipidinduced migration through porous membranes or on 2D substrata. MT1-MMP was identified as a key proteinase involved in lipid agonist-induced invasion in our systems. A schematic summarizing this data is presented in Figure 15. These results summarily address the importance of LPA and S1P in tumor motility and invasion, and directly link lipid agonist-induced tumor cell invasion of 3D collagen matrices to proteolysis via MT1-MMP.

It is clear that tumor cell migration and invasion are multifaceted events that require a myriad of cellular processes to act in concert to achieve cell movement and propulsion through natural barriers. The systems described here illustrate innovative ways to study the molecules involved in tumor locomotion. Using our systems, we identified molecular components (e.g. $\mathrm{LPA}_{1}, \mathrm{~S}_{1} \mathrm{P}_{1}, \mathrm{Rac} 1, \mathrm{Cdc} 42$, and MT1-MMP) involved in lipid-induced HT1080 invasion (Figs. 4, 5, 6, 7, 8, 9, 10, 11, 12, 13, 14). We also quantitated the effects of LPA, S1P, or reduced MT1-MMP protein expression on the distance and rate of HT1080 invasion using a new time-lapse analysis system (Figs. 3, $8,13,14$, and Tables 1 and 2). We believe that these in vitro 3D microassay collagen invasion systems represent an important and attractive approach to study the molecular requirements for tumor invasion and the mechanisms underlying the ability of single tumor cells to invade through 3D collagen matrices. Identifying the key molecules involved in tumor migration and invasion will provide better comprehension of these processes and ulti- mately, may yield more specific cancer therapeutics, particularly those that target lipid agonist-induced migration and MT1-MMP-mediated invasion.

\section{Methods \\ Reagents}

48-well micro-chemotaxis chambers and polycarbonate membranes ( $8 \mu \mathrm{m}$ pores) were purchased from Neuro Probe, Inc. (Gaithersburg, MD). D-Erythro-sphingosine 1phosphate (S1P) and lysophosphatidic acid (LPA) 1-oleoyl-2-hydroxy-SN-glycero-3-phosphate, sodium salt were purchased from Avanti Polar Lipids (Alabaster, AL). Rat tail collagen type I was prepared at $7.1 \mathrm{mg} / \mathrm{ml}$ using the method previously described [68]. Tumor cell lines were purchased from American Type Culture Collection (ATCC) (Manassas, VA). Dulbecco's Modified Eagle Medium (DMEM), Lipofectamine 2000, and fetal bovine serum (FBS) were from Invitrogen Life Technologies (Rockville, MD). Bovine TIMP-1 and TIMP-2 were obtained from Chemicon Corp (Temecula, CA). Recombinant TIMP-3 and TIMP-4 were from R\&D Systems (Minneapolis, MN). A rabbit polyclonal antibody was prepared against recombinant green fluorescent protein (GFP) as described [69]. Human MT1-MMP (AF918, R\&D Systems, Minneapolis, MN), MT3-MMP (RP1-MMP-16, Triple Point Biologics, Forest Grove, OR), and Rac1 (ARC01, Cytoskeleton, Denver, CO), and monoclonal antibodies directed against human MT2-MMP (MAB916, R\&D Systems), Lamin A/C (MAB3211, Chemicon Corp), Actin (JLA-20, Calbiochem, San Diego, CA), RhoA (ARH01, Cytoskeleton), and Cdc42 (610929, BD Tans- 
duction, San Jose, CA) were used for Western blot analysis as described previously [70]. siGENOME SMARTpool ${ }^{\circledast}$ reagents were products of Dharmacon (Lafayette, CO). Plasmids encoding human MT1-MMP (EX-M0327-M02) and MT3-MMP (EX-Q0300-M02) were obtained from Genecopoeia (Germantown, MD). A plasmid encoding human MT2-MMP (TC118648) was purchased from Origene (Rockville, $\mathrm{MD}$ ). Other reagents were obtained from Sigma (St. Louis, MO) unless noted.

\section{Cell culture}

Tumor cells were cultured in T-75 flasks and supplied with DMEM supplemented with 10\% FBS containing $100 \mu \mathrm{g} /$ $\mathrm{ml}$ gentamicin (Invitrogen), $100 \mu \mathrm{g} / \mathrm{ml}$ of streptomycin, 100 Units $/ \mathrm{ml}$ of penicillin, and $0.25 \mu \mathrm{g} / \mathrm{ml}$ Amphotericin B [Fungizone ${ }^{\circledast}$, Invitrogen, Carlsbad, CA), and incubated at $37^{\circ} \mathrm{C}$ with $5.0 \% \mathrm{CO}_{2}$. The stable $\mathrm{HT} 1080$ cell line expressing nuclear-GFP was cultured in media containing $10 \mu \mathrm{g} / \mathrm{ml}$ Blasticidin (Invitrogen). HEK293 cells were cultured on flasks pre-coated with $20 \mu \mathrm{g} / \mathrm{ml}$ type I collagen in PBS. Prior to use in experiments, cells were washed with phosphate buffered saline (PBS), removed from monolayer with trypsin-EDTA, neutralized with fetal bovine serum, and centrifuged. Cells were then washed in two, 10 $\mathrm{ml}$ volumes of DMEM to remove residual serum.

\section{Generation of stable HTI080s expressing nuclear- localized GFP}

A vector expressing nuclear-localized GFP (Nuc-GFP) (vector pACGFP1-Nuc, 632431) was obtained from BD Biosciences-Clontech (Mountain View, CA). The Nuc-GFP insert was amplified via PCR using the following primers: Nuc-GFP UP: 5'-CACCATGGTGAGCAAGGGCGCCGAG3' and Nuc-GFP DN: 5'-AGCAGTTATCTAGATCCGGTGGATC-3'. PCR product size was verified via agarose gel electrophoresis, and following PCR purification (Qiagen, Valencia, CA), was TOPO cloned into the pLenti6/V5-DTOPO lentiviral vector (Invitrogen). Following TOPO cloning, One Shot Stbl3 Chemically Competent E. coli were transformed with DNA. Individual clones containing the Nuc-GFP insert were verified via PCR and sequence analysis. The 293FT lentiviral packaging cell line was obtained from the ViraPower Lentiviral Gateway Expression Kit (Invitrogen) and were cultured in $500 \mu \mathrm{g} /$ $\mathrm{ml}$ G418. Nuc-GFP lentivirus was produced following the Invitrogen lentivirus protocol. HT1080s were infected with Nuc-GFP lentivirus and were incubated for 72 hours prior selection using $10 \mu \mathrm{g} / \mathrm{ml}$ of Blasticidin. HT1080s were cultured in Blasticidin for 10 days to ensure stable cell line selection, and Nuc-GFP expression was verified via fluorescent microscopy.

\section{6-well A/2 vertical collagen invasion assay}

Three-dimensional (3D) collagen type I invasion assays were adapted from previously described work [28].
Briefly, collagen gels ( $\mathrm{n}=3$ gels per condition, $25 \mu \mathrm{l}$ volume) were prepared as described [71] at a final concentration of 2.0 or $3.75 \mathrm{mg} / \mathrm{ml}$ and added to $\mathrm{A} / 2$ wells $(4.5 \mathrm{~mm}$ diameter) of 96-well plates (Costar, Corning, NY). $1 \mu \mathrm{M}$ S1P and/or LPA were incorporated into each gel prior to polymerization and equilibration at $37^{\circ} \mathrm{C}$ and $5 \% \mathrm{CO}_{2}$ for 45 minutes. After equilibration, $100 \mu \mathrm{l}$ of media containing a 1:250 dilution of RSII(+) (Transferrin, BSA, oleic acid, and insulin) and 35,000 tumor cells were added to each well. Cells were allowed to invade $3 \mathrm{D}$ collagen gels for 48 hours. Culture media was removed and collagen gels containing invading tumor cells were fixed in 3\% glutaraldehyde in PBS for 30 minutes. Gels were stained with $0.1 \%$ toluidine blue in $30 \%$ methanol for 30 minutes prior to destaining with water. Transected gels were imaged using an inverted Nikon Eclipse TE2000-U microscope, camera, and Metamorph ${ }^{\circledast}$ software (Molecular Devices Corporation, Downington, PA) or were acquired using an inverted Olympus microscope, camera, and Kodachrome 64T color film. Kodachrome images were scanned using a Polaroid SprintScan 4000 and PolaColor Insight Software (Polaroid, Cambridge, MA). To quantitate invasion of tumor cells in 3D collagen gels, cells were counted with eyepiece equipped with an ocular grid. For each condition, twenty random fields were selected and the number of invading cells per high power field (HPF) was counted manually at $20 \times$ magnification. Data are reported as mean number of invading cells per HPF $( \pm$ S.D.).

\section{Effects of metalloproteinase inhibitors and pertussis toxin on migration or invasion}

GM6001 (Calbiochem) and TAPI-1 (Chemicon) were reconstituted in DMSO at $2.5 \mathrm{mM}$. TAPI-0 (Chemicon) was reconstituted in DMSO at $0.25 \mathrm{mM}$. TIMP-1, TIMP-2, TIMP-3, and TIMP-4 were prepared at $100 \mu \mathrm{g} / \mathrm{ml}$ in $0.1 \%$ BSA. To determine the effects of MMP inhibitors on tumor cell migration and invasion, GM6001 $(5 \mu \mathrm{M})$, TAPI-1 (5 $\mu \mathrm{M})$, TAPI-0 $(5 \mu \mathrm{M})$, and TIMPs $1-4(5 \mu \mathrm{g} / \mathrm{ml})$ were added to upper chambers of migration assays and directly to cell media in invasion assays. Likewise, $100 \mathrm{ng} / \mu \mathrm{l}$ of pertussis toxin was added to cell media where noted. Migration and invasion assays were performed as described.

\section{Transfection of HTIO80 cells with siRNA}

siGENOME SMART pool $^{\circledR}$ human MMP-2, MMP-9, MT1MMP, MT2-MMP, MT3-MMP, LPA $1-3$, S1P $_{1-3}$, RhoA, Rac1, and Cdc42 were purchased from Dharmacon. A 21nucleotide custom MT1-MMP siRNA described previously by Weiss and colleagues [5] was prepared by Dharmacon. A Lamin A/C siGENOME SMARTpool ${ }^{\circledast}$ siRNA and a Luciferase GL2 duplex siRNA oligo (Dharmacon) were utilized as controls. All siRNA transfections were performed as described previously [72]; however, Lipofectamine 
2000 and $20 \%$ serum were utilized for transfection purposes. Cells were allowed to recover from siRNA transfection for 18 hours prior to initiation of experiments. Cells were allowed to invade for 48 hours as described above, after which conditioned media were collected and stored at $-20^{\circ} \mathrm{C}$. Invading tumor cells were extracted from collagen matrices and stored at $-20^{\circ} \mathrm{C}$ as described previously [72]. The remaining wells were fixed, stained, quantitated, and imaged as described.

\section{Transfection of HEK293 cells with plasmids encoding human MT-MMPs}

Plasmids encoding human MT1-, MT2-, and MT3-MMP cDNA were purified using the Qiagen plasmid MIDI kit (Valencia, CA). T-25 flasks were pre-coated with type I collagen as described above, and HEK293 cells were cultured to $80 \%$ confluency in $5 \mathrm{ml}$ of culture media. On the day of transfection, $6 \mu \mathrm{g}$ of MT1, MT2, or MT3-MMP plasmid DNA or the control vector pAdTrack-CMV encoding GFP [73], kindly provided by Dr. Bert Vogelstein (Johns Hopkins University College of Medicine, Baltimore, MD), was diluted into Opti-MEM I (Invitrogen) and mixed with Lipofectamine 2000 to a final volume of $1 \mathrm{ml}$. The plasmid/Lipofectamine 2000/Opti-MEM solution was added to the cells prior to overnight incubation. Cells were washed, trypsinized, and seeded onto $2.0 \mathrm{mg} / \mathrm{ml}$ collagen matrices as described above. Transfected HEK293 cells were allowed to invade for 48 hours prior to fixation, staining, and quantification as described above. For each plasmid, protein expression was verified via Western blot analysis.

\section{Real-Time Quantitative PCR (RTQ-PCR)}

$L P A_{1}$ and $S 1 P_{1}$ mRNA were quantified using the Applied Biosystem apparatus 7500 Fast Real-Time PCR system. Briefly, total RNA was extracted from siRNA-treated (Luciferase, $\mathrm{LPA}_{1}$, and $\left.\mathrm{S}_{1} \mathrm{P}_{1}\right) \mathrm{HT} 1080$ cells using the Totally RNA Isolation kit (Ambion, Austin, TX) according to the manufacturer's instructions. RNA (5 $\mu \mathrm{g})$ was reversed transcribed using StrataScript First Strand Synthesis System (Stratagene, Cedar Creek, TX). RTQ-PCR was performed in a final volume of $20 \mu \mathrm{l}$ containing $2 \mu \mathrm{l}$ of a 1:5 dilution of each RNA template, $10 \mu \mathrm{l}$ of a $\operatorname{TaqMan}^{\circledast}$ Fast Universal PCR Master Mix, and $1 \mu \mathrm{l}$ of a TaqMan ${ }^{\circledast}$ Gene Expression Assays (Applied Biosystems, Foster City, CA). Primers were designed using PrimerExpress sofware (Applied Biosystems), and targeted sequences between Exon 1 and Exon $2\left(S 1 P_{1}\right)$, between Exon 2 and Exon 3 $\left(L P A_{1}\right)$, and an inventoried eukaryotic $18 S$ rRNA (internal control). Each sample was assayed using three replicates for each primer. The $18 \mathrm{~S}$ rRNA-specific primer was used as an internal standard. The cycling conditions were as follows: one cycle at $95^{\circ} \mathrm{C}$ for 20 seconds, followed by 40 cycles of PCR amplification, each consisting of $95^{\circ} \mathrm{C}$ for 3 seconds and $60^{\circ} \mathrm{C}$ for 30 seconds. $\Delta C t$ values were obtained by subtracting the $C t$ value of the housekeeping gene $18 s r R N A$ from the $C t$ value for each indicated gene. The $\Delta \Delta C_{t}$ relative expression method was used to normalize $L P A_{1}$ and $S 1 P_{1}$ to $18 s r R N A$ as a housekeeping gene (comparative $C_{t}$ method). Data are reported as mean expression values normalized to $18 \mathrm{~s} R N A( \pm$ S.D.) of three replicates per siRNA treatment.

\section{Gelatin zymography and Western blotting}

Gelatin zymography was performed with SDS-PAGE gels containing $8.5 \%$ acrylamide and $1 \mathrm{mg} / \mathrm{ml}$ porcine gelatin. Conditioned media from the HT1080 siRNA transfected cells were prepared under non-reducing conditions. Gel electrophoresis was performed at $150 \mathrm{~V}$ for 55 minutes. Zymograms were incubated for three 20 minute periods in $100 \mathrm{mls}$ of $2 \%$ Triton X-100 in water, washed twice in distilled water, placed in $25 \mathrm{mM}$ Tris- $\mathrm{HCl}$ (pH 7.5) containing $5 \mathrm{mM} \mathrm{CaCl}_{2}$, and incubated overnight at room temperature. The following morning, gels were stained with $0.1 \%$ Amido Black in $30 \%$ methanol and $10 \%$ acetic acid for $15 \mathrm{~min}$ and destained in 30\% methanol and 10\% acetic acid for 1 hour at room temperature. Western blot analysis was performed using $10 \%$ or $14 \%$ (for RhoA, Rac1, and Cdc42) SDS-PAGE gels as described previously [70] and probed with antibodies at the following concentrations: GFP, $0.1 \mu \mathrm{g} / \mathrm{ml}$; MT1-MMP, $2 \mu \mathrm{g} / \mathrm{ml}$; MT2-MMP, $1 \mu \mathrm{g} / \mathrm{ml}$; MT3-MMP, $1 \mu \mathrm{g} / \mathrm{ml}$; Lamin A/C, $2 \mu \mathrm{g} / \mathrm{ml}$; Actin, $0.1 \mu \mathrm{g} / \mathrm{ml}$; RhoA, $2 \mu \mathrm{g} / \mathrm{ml}$; Rac1, $5 \mu \mathrm{g} / \mathrm{ml}$; and Cdc42, 2 $\mu \mathrm{g} / \mathrm{ml}$

\section{Time-lapse measurements and imaging of HTI080 invasion}

Hollow glass casings $(3 \times 3 \times 8 \mathrm{~mm})$ were designed by Wale Apparatus (Hellertown, PA) to accommodate a collagen gel and tumor cells during invasion. Collagen gels were prepared at a final concentration of $3.75 \mathrm{mg} / \mathrm{ml}$. 1 $\mu \mathrm{M}$ of S1P and/or LPA was incorporated into each gel before filling each glass casing with $\sim 20 \mu \mathrm{l}$ of collagen. Gels were allowed to polymerize and equilibrate at $37^{\circ} \mathrm{C}$ with $5 \% \mathrm{CO}_{2}$ for 45 minutes. After equilibration, $50 \mu \mathrm{l}$ of clear DMEM (Invitrogen) containing 25,000 HT1080 cells was added to the upper portion of the glass casing above the collagen. Cells were allowed to attach for 30 minutes before the glass casings were secured in a horizontal plane within the well of a 48 well plate (Costar) with sterile silicon grease. Each well was then supplied with $500 \mu \mathrm{l}$ of media containing a 1:250 dilution RSII $(+)$. Cells were allowed to invade for 48 hours at $37^{\circ} \mathrm{C}$ with $5 \% \mathrm{CO}_{2}$. Digital images were captured directly every ten minutes using an inverted Nikon Eclipse TE2000-U microscope, camera, and Metamorph ${ }^{\circledast}$ software (Molecular Devices Corporation, Downington, PA). Using Metamorph ${ }^{\oplus}$, images of individual fields of invading tumor cells were arranged in sequential order. Distance of HT1080 invasion was measured using digital pixel measurements and plotted against 
time using Microsoft Excel $^{\circledR}$. Rate of invasion was determined using linear regression statistical analysis. Data are reported as the mean distance in micrometers of invading cell fronts $( \pm$ S.D.). Five measurements for each time point of duplicate or triplicate experiments were performed.

\section{Assessment of chemotactic migration}

Modified Boyden chambers were utilized to assess lipidinduced chemotactic directional migration. Polycarbonate filters ( $8 \mu \mathrm{m}$ pores) were pre-coated with $1 \mathrm{mg} / \mathrm{ml}$ type I collagen or gelatin in PBS. LPA and/or S1P in DMEM containing a 1:250 dilution of reduced serum II supplement [RSII(-)] (Transferrin, BSA, no oleic acid, and insulin) were added to lower wells. Upper wells contained a 1:250 dilution of RSII(-) and lower wells contained 20 $\mu \mathrm{g} / \mathrm{ml}$ of fibronectin for gelatin-coated membranes. $5 \times$ $10^{4}$ tumor cells were added to upper chambers and allowed to migrate for 4 hours. Filters were removed and stained with $0.1 \%$ amido black in $30 \%$ methanol and $10 \%$ acetic acid. Membrane-adherent migrating cells were calculated using Scion ${ }^{\circledR}$ image and Microsoft ${ }^{\circledR}$ Excel. Migration data are represented mean number of migrating cells $\times 10^{3}$ ( \pm S.D.) and represent the results of quadruplicate experiments.

\section{Tracking Nuclear-GFP HTI 080 cells on collagen-coated} plastic (2D) or embedded within in collagen matrices (3D) To observe the movement of HT1080 cells embedded in 3D collagen matrices, nuc-GFP HT1080s or siRNA treated (Luciferase or custom MT1-MMP) nuc-GFP HT1080s were mixed 1:1 with non-fluorescent HT1080s. Cells were then incorporated into a $3.75 \mathrm{mg} / \mathrm{ml}$ collagen matrix ( $n=3$ cultures per condition) containing $1 \mu \mathrm{M}$ LPA. $15 \mu \mathrm{l}$ of collagen and cell mixtures were added to square 384-well tissue culture plates (VWR, West Chester, PA), and allowed to equilibrate for 1 hour prior to addition of 60 $\mu \mathrm{l}$ of media containing a 1:250 dilution of RSII(+). $5 \mu \mathrm{M}$ GM6001 was added to the media as noted. Cells were allowed to invade the surrounding matrix for 48 hours at $37^{\circ} \mathrm{C}$ with $5 \% \mathrm{CO}_{2}$. Digital fluorescent images were captured directly with Metamorph ${ }^{\circledast}$ as described above. By tracking fluorescent nuclei in chronological frames, Metamorph $^{\circledast}$ generated cell tracings of the movements of individual cells. For 2D tracings, nuclear-GFP HT1080 cells were seeded on 6 well plates pre-coated (30 minutes) with $50 \mu \mathrm{g} / \mathrm{ml}$ of type I collagen and cultured with $2 \mathrm{mls}$ of media containing a 1:250 dilution of RSII (+). GM6001 was added as described. Images and cell tracings were generated by Metamorph ${ }^{\circledast}$ as described.

\section{Competing interests}

The authors declare that there are no competing interests.

\section{Authors' contributions}

KEF drafted the manuscript, designed and performed all 3D and siRNA experiments, carried out data analysis, and helped conceive the manuscript. AP designed and performed the initial migration experiments. WK assisted in the initial migration experiments and their design. NJA assisted in the initial migration experiments as well as the data analysis. WBS created the nuclear GFP lentivirus, participated in the 2D motility analysis, and assisted in drafting the manuscript. GED conceived the study, participated in its design and execution, and helped conceive and draft the manuscript.

\section{Additional material}

\section{Additional file 1}

LPA-induced HT1080 invasion of a 3D collagen matrix over 24 hours. Time-lapse image analysis over 24 hours of HT1080 invasion through a $3.75 \mathrm{mg} / \mathrm{ml}$ three-dimensional collagen matrix containing $1 \mu \mathrm{M} \mathrm{LPA}$. Click here for file

[http://www.biomedcentral.com/content/supplementary/14764598-5-69-S1.avi]

\section{Additional file 2}

LPA-induced HT1080 invasion of 3D collagen matrix in the presence of $5 \mu \mathrm{M}$ GM6001 over 24 hours. Time-lapse image analysis over 24 hours of HT1080 invasion through a $3.75 \mathrm{mg} / \mathrm{ml}$ three-dimensional collagen matrix containing $1 \mu \mathrm{M}$ LPA with $5 \mu \mathrm{M}$ GM6001 supplied in the media. Click here for file

[http://www.biomedcentral.com/content/supplementary/14764598-5-69-S2.avi]

\section{Additional file 3}

LPA-induced migration of Nuc-GFP HT1080 cells over 24 hours seeded on plastic coated with $50 \mu \mathrm{g} / \mathrm{ml}$ of collagen. Fluorescent time-lapse image analysis over 24 hours of Nuc-GFP HT1080 cells seeded on plastic coated with $50 \mu \mathrm{g} / \mathrm{ml}$ of collagen treated with $1 \mu \mathrm{M} \mathrm{LPA}$

Click here for file

[http://www.biomedcentral.com/content/supplementary/14764598-5-69-S3.avi]

\section{Additional file 4}

LPA-induced migration of Nuc-GFP HT1080 cells over 24 hours seeded on plastic coated with $50 \mu \mathrm{g} / \mathrm{ml}$ of collagen in the presence of $5 \mu \mathrm{M}$ GM6001. Fluorescent time-lapse image analysis over 24 hours of NucGFP HT1080 cells seeded on plastic coated with $50 \mu \mathrm{g} / \mathrm{ml}$ of collagen treated with $1 \mu \mathrm{M} \mathrm{LPA}$ and $5 \mu \mathrm{M}$ GM6001

Click here for file

[http://www.biomedcentral.com/content/supplementary/14764598-5-69-S4.avi]

\section{Additional file 5}

LPA-induced invasion of Nuc-GFP HT1080 cells embedded in a 3D collagen matrix over 24 hours. Fluorescent time-lapse image analysis over 24 hours of Nuc-GFP HT1080 cells embedded in a $3.75 \mathrm{mg} / \mathrm{ml}$ collagen matrix containing $1 \mu \mathrm{M} L P A$

Click here for file

[http://www.biomedcentral.com/content/supplementary/14764598-5-69-S5.avi] 


\section{Additional file 6 \\ LPA-induced invasion of Nuc-GFP HT1080 cells embedded in a 3D col- lagen matrix over 24 hours with $5 \mu \mathrm{M}$ GM6001. Fluorescent time-lapse image analysis over 24 hours of Nuc-GFP HT1080 cells embedded in a $3.75 \mathrm{mg} / \mathrm{ml}$ collagen matrix containing $1 \mu \mathrm{M}$ LPA with $5 \mu \mathrm{M}$ GM6001 supplied in the media. \\ Click here for file \\ [http://www.biomedcentral.com/content/supplementary/1476- 4598-5-69-S6.avi] \\ Additional file 7 \\ LPA-induced HT1080 invasion of 3D collagen matrix in the presence of $5 \mu \mathrm{g} / \mathrm{ml}$ of TIMP-1 over 24 hours. Time-lapse image analysis over 24 hours of HT1080 invasion through a $3.75 \mathrm{mg} / \mathrm{ml}$ three-dimensional col- lagen matrix containing $1 \mu \mathrm{M}$ LPA with $5 \mu \mathrm{g} / \mathrm{ml}$ of TIMP-1 supplied in the media. \\ Click here for file \\ [http://www.biomedcentral.com/content/supplementary/1476- 4598-5-69-S7.avi] \\ Additional file 8 \\ LPA-induced HT1080 invasion of 3D collagen matrix in the presence of $5 \mu \mathrm{g} / \mathrm{ml}$ of TIMP-3 over 24 hours. Time-lapse image analysis over 24 hours of HT1080 invasion through a $3.75 \mathrm{mg} / \mathrm{ml}$ three-dimensional col- lagen matrix containing $1 \mu \mathrm{M}$ LPA with $5 \mu \mathrm{g} / \mathrm{ml}$ of TIMP-3 supplied in the media. \\ Click here for file \\ [http://www.biomedcentral.com/content/supplementary/1476- 4598-5-69-S8.avi]}

\section{Acknowledgements}

This work was supported by NIH grants HL59373 and HL79460 (to GED). The authors would like to thank Andrea Nolte, Aaron Mobley, and Jennifer Faske for their excellent technical assistance.

\section{References}

I. Stetler-Stevenson WG, Aznavoorian S, Liotta LA: Tumor cell interactions with the extracellular matrix during invasion and metastasis. Annu Rev Cell Biol I993, 9(I):54I-573.

2. Mignatti $P$, Rifkin DB: Biology and biochemistry of proteinases in tumor invasion. Physiol Rev 1993, 73(1): I61-195.

3. Fried $\mathrm{P}$, Wolf $\mathrm{K}$ : Tumour-cell invasion and migration: diversity and escape mechanisms. Nat Rev Cancer 2003, 3(5):362-374.

4. Gehlsen KR, Davis GE, Sriramarao P: Integrin expression in human melanoma cells with differing invasive and metastatic properties. Clin Exp Metastasis 1992, I 0(2): I I I-I20.

5. Sabeh F, Ota I, Holmbeck K, Birkedal-Hansen H, Soloway P, Balbin M, Lopez-Otin C, Shapiro S, Inada M, Krane S, Allen E, Chung D, Weiss SJ: Tumor cell traffic through the extracellular matrix is controlled by the membrane-anchored collagenase MTI-MMP. J Cell Biol 2004, I67(4):769-78I.

6. Seiki M: Membrane-type I matrix metalloproteinase: a key enzyme for tumor invasion. Cancer Lett 2003, I 94(I): I-II.

7. Chambers AF, Groom AC, MacDonald IC: Dissemination and growth of cancer cells in metastatic sites. Nat Rev Cancer 2002, 2(8):563-572.

8. Ridley AJ, Schwartz MA, Burridge K, Firtel RA, Ginsberg MH, Borisy G, Parsons JT, Horwitz AR: Cell migration: integrating signals from front to back. Science 2003, 302(565 I): I 704-I 709.

9. Hanahan D, Weinberg RA: The Hallmarks of Cancer. Cell 2000, I 00(I):57-70.

10. Sporn MB: The war on cancer. The Lancet 1996, 347(9012): |377-138|.

II. Hla T: Signaling and biological actions of sphingosine I-phosphate. Pharmacol Res 2003, 47(5):401-407.
12. Goetzl EJ, Wang W, McGiffert C, Huang MC, Graler MH: Sphingosine I-phosphate and its $\mathbf{G}$ protein-coupled receptors constitute a multifunctional immunoregulatory system. J Cell Biochem 2004, 92(6): I I 04- I I |4.

13. Lee H, Goetzl EJ, An S: Lysophosphatidic acid and sphingosine I-phosphate stimulate endothelial cell wound healing. $\mathrm{Am} \mathrm{J}$ Physiol Cell Physiol 2000, 278(3):C6I2-8.

14. Saba JD: Lysophospholipids in development: Miles apart and edging in. J Cell Biochem 2004, 92(5):967-992.

15. Panetti TS: Differential effects of sphingosine I-phosphate and lysophosphatidic acid on endothelial cells. Biochim Biophys Acta 2002, I 582(I-3): 190-196.

16. Kluk MJ, Hla T: Signaling of sphingosine-I-phosphate via the SIP/EDG-family of G-protein-coupled receptors. Biochim Biophys Acta 2002, I 582(I-3):72-80.

17. Whitehead IP, Zohn IE, Der CJ: Rho GTPase-dependent transformation by $\mathbf{G}$ protein-coupled receptors. Oncogene 200I, 20(I3): I547-I555.

18. Moolenaar WH: Bioactive lysophospholipids and their $\mathbf{G}$ protein-coupled receptors. Exp Cell Res I999, 253(I):230-238.

19. Moolenaar WH: Lysophosphatidic Acid, a Multifunctional Phospholipid Messenger. J Biol Chem 1995, 270(22): I2949-12952.

20. Kostenis E: Novel clusters of receptors for sphingosine-Iphosphate, sphingosylphosphorylcholine, and (lyso)-phosphatidic acid: new receptors for "old" ligands. J Cell Biochem 2004, 92(5):923-936.

21. Spiegel S, Milstien S: Sphingosine-I-phosphate: an enigmatic signalling lipid. Nat Rev Mol Cell Biol 2003, 4(5):397-407.

22. Umezu-Goto M, Kishi Y, Taira A, Hama K, Dohmae N, Takio K, Yamori T, Mills GB, Inoue K, Aoki J, Arai H: Autotaxin has lysophospholipase $D$ activity leading to tumor cell growth and motility by lysophosphatidic acid production. J Cell Biol 2002, I 58(2):227-233.

23. Mills GB, Eder A, Fang X, Hasegawa $Y$, Mao M, Lu Y, Tanyi J, Tabassam FH, Wiener J, Lapushin R, Yu S, Parrott JA, Compton T, Tribley W, Fishman D, Stack MS, Gaudette D, Jaffe R, Furui T, Aoki J, Erickson JR: Critical role of lysophospholipids in the pathophysiology, diagnosis, and management of ovarian cancer. Cancer Treat Res 2002, I 07:259-283.

24. Fishman DA, Liu Y, Ellerbroek SM, Stack MS: Lysophosphatidic acid promotes matrix metalloproteinase (MMP) activation and MMP-dependent invasion in ovarian cancer cells. Cancer Res 200I, 6 I(7):3194-3199.

25. Mills GB, Moolenaar WH: The emerging role of lysophosphatidic acid in cancer. Nat Rev Cancer 2003, 3(8):582-591.

26. Milstien S, Spiegel S: Targeting sphingosine-I-phosphate: a novel avenue for cancer therapeutics. Cancer Cell 2006, 9(3): $148-150$

27. Moolenaar WH, van Meeteren LA, Giepmans BN: The ins and outs of lysophosphatidic acid signaling. Bioessays 2004, 26(8):870-88I.

28. Bayless KJ, Davis GE: Sphingosine I-phosphate markedly induces matrix metalloproteinase and integrin-dependent human endothelial cell invasion and lumen formation in three-dimensional collagen and fibrin matrices. Biochem Biophys Res Commun 2003, 3 I 2(4):903-913.

29. Langlois S, Gingras D, Beliveau R: Membrane type I-matrix metalloproteinase (MTI-MMP) cooperates with sphingosine Iphosphate to induce endothelial cell migration and morphogenic differentiation. Blood 2004, I 03(8):3020-3028.

30. Stetler-Stevenson WG, Yu AE: Proteases in invasion: matrix metalloproteinases. Semin Cancer Biol 200 I, I I (2): | 43-I 52.

31. Egeblad M, Werb Z: New functions for the matrix metalloproteinases in cancer progression. Nat Rev Cancer 2002, 2(3): $161-174$

32. Foda HD, Zucker S: Matrix metalloproteinases in cancer invasion, metastasis and angiogenesis. Drug Discov Today 200I, 6(9):478-482

33. Itoh $\mathrm{Y}$, Nagase $\mathrm{H}$ : Matrix metalloproteinases in cancer. Essays Biochem 2002, 38:21-36.

34. Vihinen $\mathrm{P}$, Ala-aho $\mathrm{R}$, Kahari VM: Matrix metalloproteinases as therapeutic targets in cancer. Curr Cancer Drug Targets 2005, 5(3):203-220. 
35. Coussens LM, Fingleton B, Matrisian LM: Matrix metalloproteinase inhibitors and cancer: trials and tribulations. Science 2002 295(5564):2387-2392.

36. Ohuchi E, Imai K, Fujii Y, Sato H, Seiki M, Okada Y: Membrane type I matrix metalloproteinase digests interstitial collagens and other extracellular matrix macromolecules. J Biol Chem 1997 272(4):2446-245I.

37. Hotary K, Allen E, Punturieri A, Yana I, Weiss SJ: Regulation of cell invasion and morphogenesis in a three-dimensional type I collagen matrix by membrane-type matrix metalloproteinases I, 2, and 3. J Cell Biol 2000, I49(6): I 309-I323.

38. Yana I, Seiki M: MT-MMPs play pivotal roles in cancer dissemination. Clin Exp Metastasis 2002, I 9(3):209-2I5.

39. Rozanov DV, Deryugina EI, Ratnikov BI, Monosov EZ, Marchenko GN, Quigley JP, Strongin AY: Mutation analysis of membrane type-I matrix metalloproteinase (MTI-MMP). The role of the cytoplasmic tail Cys(574), the active site Glu(240), and furin cleavage motifs in oligomerization, processing, and self-proteolysis of MTI-MMP expressed in breast carcinoma cells. J Biol Chem 200I, 276(28):25705-257। 4

40. Davis GE, Senger DR: Endothelial extracellular matrix: biosynthesis, remodeling, and functions during vascular morphogenesis and neovessel stabilization. Circ Res 2005 97( I I): 1093-I I07.

41. Peterson H, Reeves B, Brown R, Hall A, Furth M, Bos J, Jones P, Marshall C: Activated N-ras Controls the Transformed Phenotype of HTI080 Human Fibrosarcoma Cells. Cell 1987, 51:803-812.

42. Rasheed S, Nelson Rees WA, Toth EM, Arnstein P, Gardner MB: Characterisation of a newly derived human sarcoma cell line (HT 1080). Cancer 1974, 33(4): I027-1033.

43. Siehler S, Manning DR: Pathways of transduction engaged by sphingosine I-phosphate through $\mathbf{G}$ protein-coupled receptors. Biochimica et Biophysica Acta (BBA) - Molecular and Cell Biology of Lipids 2002, I 582(1-3):94-99.

44. Ye X, Ishii I, Kingsbury MA, Chun J: Lysophosphatidic acid as a novel cell survival/apoptotic factor. Biochim Biophys Acta 2002, I 585(2-3): I08-I|3.

45. Price LS, Collard JG: Regulation of the cytoskeleton by Rhofamily GTPases: implications for tumour cell invasion. Semin Cancer Biol 200I, I I(2): I67-173.

46. Schmitz AA, Govek EE, Bottner B, Van Aelst L: Rho GTPases: signaling, migration, and invasion. Exp Cell Res 2000, 26 I(I): I-I2

47. Okamoto H, Takuwa N, Yokomizo T, Sugimoto N, Sakurada S, Shigematsu $H$, Takuwa $Y$ : Inhibitory regulation of Rac activation, membrane ruffling, and cell migration by the $G$ protein-coupled sphingosine-I-phosphate receptor EDG5 but not EDG I or EDG3. Mol Cell Biol 2000, 20(24):9247-926I.

48. Radeff-Huang J, Seasholtz TM, Matteo RG, Brown JH: G protein mediated signaling pathways in lysophospholipid induced cell proliferation and survival. I Cell Biochem 2004, 92(5):949-966.

49. Wolf K, Mazo I, Leung H, Engelke K, von Andrian UH, Deryugina EI, Strongin AY, Brocker EB, Friedl P: Compensation mechanism in tumor cell migration: mesenchymal-amoeboid transition after blocking of pericellular proteolysis. I Cell Biol 2003 I 60(2):267-277.

50. Nabeshima K, Inoue T, Shimao Y, Sameshima T: Matrix metalloproteinases in tumor invasion: role for cell migration. Pathol Int 2002, 52(4):255-264.

5I. Seiki M, Mori H, Kajita M, Uekita T, Itoh Y: Membrane-type I matrix metalloproteinase and cell migration. Biochem Soc Symp 2003:253-262.

52. Visse $\mathrm{R}, \mathrm{Nagase} \mathrm{H}$ : Matrix metalloproteinases and tissue inhibitors of metalloproteinases: structure, function, and biochemistry. Circ Res 2003, 92(8):827-839.

53. Lambert E, Dasse E, Haye B, Petitfrere E: TIMPs as multifacial proteins. Crit Rev Oncol Hematol 2004, 49(3): I87-198.

54. Hotary KB, Allen ED, Brooks PC, Datta NS, Long MW, Weiss SJ: Membrane type I matrix metalloproteinase usurps tumor growth control imposed by the three-dimensional extracellular matrix. Cell 2003, I | 4( I):33-45.

55. Cukierman E, Pankov R, Yamada KM: Cell interactions with three-dimensional matrices. Current Opinion in Cell Biology 2002, I 4(5):633-640.
56. Xu Y, Shen Z, Wiper DW, Wu M, Morton RE, Elson P, Kennedy AW, Belinson J, Markman M, Casey G: Lysophosphatidic acid as a potential biomarker for ovarian and other gynecologic cancers. JAMA 1998, 280(8):719-723.

57. Clair T, Aoki J, Koh E, Bandle RW, Nam SW, Ptaszynska MM, Mills GB, Schiffmann E, Liotta LA, Stracke ML: Autotaxin hydrolyzes sphingosylphosphorylcholine to produce the regulator of migration, sphingosine-l-phosphate. Cancer Res 2003, 63(I 7):5446-5453.

58. Tokumura A, Majima E, Kariya Y, Tominaga K, Kogure K, Yasuda K, Fukuzawa K: Identification of human plasma lysophospholipase D, a lysophosphatidic acid-producing enzyme, as autotaxin, a multifunctional phosphodiesterase. J Biol Chem 2002, 277(42):39436-39442

59. Yamada T, Sato K, Komachi M, Malchinkhuu E, Tobo M, Kimura T, Kuwabara A, Yanagita Y, Ikeya T, Tanahashi Y, Ogawa T, Ohwada S, Morishita Y, Ohta H, Im DS, Tamoto K, Tomura H, Okajima F: Lysophosphatidic acid (LPA) in malignant ascites stimulates motility of human pancreatic cancer cells through LPAI. J Biol Chem 2004, 279(8):6595-6605.

60. Saba JD, Hla T: Point-counterpoint of sphingosine I-phosphate metabolism. Circ Res 2004, 94(6):724-734.

61. van Meeteren LA, Ruurs P, Christodoulou E, Goding JW, Takakusa H, Kikuchi K, Perrakis A, Nagano T, Moolenaar WH: Inhibition of autotaxin by lysophosphatidic acid and sphingosine I-phosphate. J Biol Chem 2005, 280(22):2II55-2 II6I.

62. Stadler CR, Knyazev P, Bange J, Ullrich A: FGFR4 GLY388 isotype suppresses motility of MDA-MB-23 I breast cancer cells by EDG-2 gene repression. Cell Signal 2006, I 8(6):783-794.

63. Deryugina El, Zijlstra A, Partridge JJ, Kupriyanova TA, Madsen MA, Papagiannakopoulos T, Quigley JP: Unexpected effect of matrix metalloproteinase down-regulation on vascular intravasation and metastasis of human fibrosarcoma cells selected in vivo for high rates of dissemination. Cancer Res 2005, 65(23): 10959-10969.

64. Visentin B, Vekich JA, Sibbald BJ, Cavalli AL, Moreno KM, Matteo RG, Garland WA, Lu Y, Yu S, Hall HS, Kundra V, Mills GB, Sabbadini RA: Validation of an anti-sphingosine- I-phosphate antibody as a potential therapeutic in reducing growth, invasion, and angiogenesis in multiple tumor lineages. Cancer Cell 2006, 9(3):225-238

65. Coussens LM, Tinkle CL, Hanahan D, Werb Z: MMP-9 supplied by bone marrow-derived cells contributes to skin carcinogenesis. Cell 2000, I03(3):481-490.

66. Schnaeker EM, Ossig R, Ludwig T, Dreier R, Oberleithner H, Wilhelmi M, Schneider SW: Microtubule-dependent matrix metalloproteinase-2/matrix metalloproteinase-9 exocytosis: prerequisite in human melanoma cell invasion. Cancer Res 2004, 64(24):8924-8931.

67. Wu WT, Chen CN, Lin Cl, Chen JH, Lee H: Lysophospholipids enhance matrix metalloproteinase-2 expression in human endothelial cells. Endocrinology 2005, I 46(8):3387-3400.

68. Bornstein MB: Reconstituted rat-tail collagen used as a substrate for tissue cultures on coverslips in Maximov slides and rollertubes. Lab Invest 1958, 7:134-137.

69. Bayless KJ, Davis GE: The Cdc42 and Racl GTPases are required for capillary lumen formation in three-dimensional extracellular matrices. J Cell Sci 2002, I I 5(6): I | 23- I I 36

70. Salazar R, Bell SE, Davis GE: Coordinate induction of the actin cytoskeletal regulatory proteins gelsolin, vasodilator-stimulated phosphoprotein, and profilin during capillary morphogenesis in vitro. Exp Cell Res 1999, 249(I):22-32.

7I. Davis GE, Camarillo CW: An alpha 2 beta I integrin-dependent pinocytic mechanism involving intracellular vacuole formation and coalescence regulates capillary lumen and tube formation in three-dimensional collagen matrix. Exp Cell Res 1996, 224(I):39-5I.

72. Saunders WB, Bayless KJ, Davis GE: MMP-I activation by serine proteases and MMP-IO induces human capillary tubular network collapse and regression in 3D collagen matrices. J Cell Sci 2005, I I 8(Pt I 0):2325-2340.

73. He TC, Zhou S, da Costa LT, Yu J, Kinzler KW, Vogelstein B: A simplified system for generating recombinant adenoviruses. PNAS 1998, 95(5):2509-25।4. 